\title{
Modeling the marine aragonite cycle: changes under rising carbon dioxide and its role in shallow water $\mathrm{CaCO}_{3}$ dissolution
}

\author{
R. Gangstø $\emptyset^{1,2}$, M. Gehlen ${ }^{1}$, B. Schneider ${ }^{1, *}$, L. Bopp ${ }^{1}$, O. Aumont ${ }^{3}$, and F. Joos ${ }^{2,4}$ \\ ${ }^{1}$ LSCE/IPSL, Laboratoire des Sciences du Climat et de l'Environnement, CEA-CNRS-UVSQ, Orme des Merisiers, Bât. 712, \\ CEA/Saclay, 91198 Gif-sur-Yvette Cedex, France \\ ${ }^{2}$ Climate and Environmental Physics, Physics Institute, University of Bern, Sidlerstr. 5, 3012 Bern, Switzerland \\ ${ }^{3}$ LOCEAN/IPSL, Centre IRD de Bretagne, BP 70, 29280 Plouzané, France \\ ${ }^{4}$ Oeschger Centre for Climate Change Research, University of Bern, Erlachstrasse 9a, 3012 Bern, Switzerland \\ * now at: Institute of Geosciences, University of Kiel, Luedwig-Meyn-Str. 10, 24098 Kiel, Germany
}

Received: 26 March 2008 - Published in Biogeosciences Discuss.: 16 April 2008

Revised: 4 July 2008 - Accepted: 7 July 2008 - Published: 28 July 2008

\begin{abstract}
The marine aragonite cycle has been included in the global biogeochemical model PISCES to study the role of aragonite in shallow water $\mathrm{CaCO}_{3}$ dissolution. Aragonite production is parameterized as a function of mesozooplankton biomass and aragonite saturation state of ambient waters. Observation-based estimates of marine carbonate production and dissolution are well reproduced by the model and about $60 \%$ of the combined $\mathrm{CaCO}_{3}$ water column dissolution from aragonite and calcite is simulated above $2000 \mathrm{~m}$. In contrast, a calcite-only version yields a much smaller fraction. This suggests that the aragonite cycle should be included in models for a realistic representation of $\mathrm{CaCO}_{3}$ dissolution and alkalinity. For the SRES A2 $\mathrm{CO}_{2}$ scenario, production rates of aragonite are projected to notably decrease after 2050. By the end of this century, global aragonite production is reduced by $29 \%$ and total $\mathrm{CaCO}_{3}$ production by $19 \%$ relative to preindustrial. Geographically, the effect from increasing atmospheric $\mathrm{CO}_{2}$, and the subsequent reduction in saturation state, is largest in the subpolar and polar areas where the modeled aragonite production is projected to decrease by $65 \%$ until 2100 .
\end{abstract}

Correspondence to: R. Gangst $\varnothing$

(gangsto@climate.unibe.ch)

\section{Introduction}

The ocean calcium carbonate $\left(\mathrm{CaCO}_{3}\right)$ budget is a topic of long standing interest in marine geochemical research (e.g. Berger, 1978; Milliman, 1993; Milliman and Droxler, 1996; Milliman et al., 1999; Iglesias-Rodriguez et al., 2002; Berelson et al., 2007). The growing awareness of the impacts of rising atmospheric $\mathrm{CO}_{2}$ concentrations on the chemistry of the ocean and related consequences on marine biota in general and calcifying organisms in particular has recently revived this area of study (e.g. Caldeira and Wickett, 2003; Feely et al., 2004; Orr et al., 2005; Royal Society, 2005, Kleypas et al., 2006). In a recent review of the marine $\mathrm{CaCO}_{3}$ cycle, Iglesias-Rodriguez et al. (2002) highlight the lack of fundamental understanding of controls of $\mathrm{CaCO}_{3}$ formation, dissolution and burial. This lack of fundamental understanding hampers our capability for assessing the present state of the carbonate system and forecasting its evolution under increasing atmospheric $\mathrm{CO}_{2}$ and global warming.

The present study focuses on one striking and yet not well explained feature of past and recent estimates of the global ocean $\mathrm{CaCO}_{3}$ budget, namely the reported loss $(60-80 \%)$ of pelagic $\mathrm{CaCO}_{3}$ production in the upper 500 to $1000 \mathrm{~m}$ of the water column (e.g. Milliman and Droxler, 1996; Berelson et al., 2007). This contradicts the general paradigm of the conservative nature of pelagic $\mathrm{CaCO}_{3}$ at shallow depths (Sverdrup et al., 1942). The latter is directly derived from the evolution with depth of the saturation product for $\mathrm{CaCO}_{3}$ minerals which increases with decreasing temperature and increasing pressure/depth (Zeebe and Wolf-Gladrow, 2001). As a consequence surface ocean waters are at present oversaturated with respect to $\mathrm{CaCO}_{3}$ (e.g. Orr et al., 2005) precluding

Published by Copernicus Publications on behalf of the European Geosciences Union. 
dissolution from a thermodynamic point of view.

Mechanisms proposed to explain the occurrence of $\mathrm{CaCO}_{3}$ dissolution above the saturation horizon invoke biological mediation. It was proposed that $\mathrm{CaCO}_{3}$ particles would dissolve after ingestion by pelagic grazers during gut passage (Harris, 1994). Until recently, dissolution during gut passage had, however, not been unequivocally demonstrated (Honjo and Roman, 1978; Pond et al., 1995). Antia et al. (2008) have shown that microzooplankton grazing may explain the reported amplitude of dissolution fluxes, while its exact quantitative contribution to shallow-water dissolution remains uncertain. Alternatively, the oxic remineralization of particulate organic $\mathrm{C}$ in aggregates could be at the origin of undersaturated microenvironments triggering the dissolution of $\mathrm{CaCO}_{3}$ particles associated to POC within the same aggregate (Milliman et al., 1999). However, Jansen et al. (2002) concluded from a modeling study that $\mathrm{CaCO}_{3}$ dissolution in marine aggregates in response to $\mathrm{CO}_{2}$ production by $\mathrm{POC}$ remineralisation is unlikely to be at the origin of observed shallow-water dissolution fluxes.

In the absence of a clear identification of processes driving shallow water $\mathrm{CaCO}_{3}$ dissolution, we might address the topic from the side of methods used to infer the order of magnitude of dissolution fluxes. On one hand, we have the evolution of $\mathrm{CaCO}_{3}$ fluxes recorded in sediment traps in comparison to upper ocean $\mathrm{CaCO}_{3}$ production estimates (e.g. Milliman et al., 1999; Feely et al., 2004; Wollast and Chou, 1998). This approach has its own set of caveats (e.g. Milliman et al., 1999; Berelson et al., 2007) the complete discussion of which is beyond the scope of this paper. On the other hand, we have tracer based approaches, in particular the alkalinity based approach TA* (Feely et al., 2002; Sabine et al., 2002; Chung et al., 2003). Conceptually, it relays on the breakdown of total alkalinity (TA) into three components: the preformed alkalinity $\mathrm{TA}^{0}$, the alkalinity of the water parcel as it leaves the surface ocean; the contribution from organic matter remineralization at depth, $\mathrm{TA}^{\mathrm{AOU}}$, and the contribution from $\mathrm{CaCO}_{3}$ dissolution at depth, TA*. Friis et al. (2006) conclude from a model based assessment of the TA* method, that this method probably overestimates the magnitude of $\mathrm{CaCO}_{3}$ dissolution at shallow water depth because this approach does not take into account the influence of water mass transport.

In the pelagic realm $\mathrm{CaCO}_{3}$ is produced mainly as two polymorphs of differing solubility: calcite (coccolithophores, foraminifera) and aragonite (mostly pteropods), the latter being $50 \%$ more soluble than calcite. The contribution of aragonite to shallow water $\mathrm{CaCO}_{3}$ dissolution is mentioned by several authors (e.g. Milliman et al., 1999; Berelson et al., 2007), but judged to be insignificant on the basis of its supposed only minor contribution to total pelagic $\mathrm{CaCO}_{3}$ production (10\% according to Fabry, 1990). Estimates of aragonite production and fluxes in the modern ocean are however scarce. Moreover these estimates cover a wide range, spreading from 10 to $50 \%$ of the total global $\mathrm{CaCO}_{3}$ flux (Berner, 1977; Berger, 1978; Berner and Honjo, 1981;
Fabry and Deuser, 1991). A significant contribution of aragonite to the reported shallow water dissolution can thus not be ruled out a priori. Our study explores the potential contribution of aragonite to shallow water $\mathrm{CaCO}_{3}$ dissolution by means of a model study. As a follow-up of Gehlen et al. (2007), we implemented aragonite production and dissolution to the global biogeochemical ocean model PISCES. In the first section of this paper, we present a global open ocean $\mathrm{CaCO}_{3}$ budget for calcite and for aragonite. Model improvements are discussed with reference to the study by Gehlen et al. (2007) which was also based on PISCES, but did only consider calcite. In the second section, we assess potential changes to the global $\mathrm{CaCO}_{3}$ budget in response to increasing atmospheric $\mathrm{CO}_{2}$ levels following the IPCC SRES A2 scenario.

\section{The PISCES model}

\subsection{General model description}

The model used in the current study is the PISCES global ocean biogeochemical model (Aumont et al., 2003; Aumont and Bopp, 2006; Gehlen et al., 2006) which simulates the biogeochemical cycle of oxygen, carbon and the main nutrients controlling marine biological productivity: nitrate, ammonium, phosphate, silicate and iron. Biological productivity is limited by the external availability of nutrients. The phosphorus and nitrogen cycles in the model are decoupled by nitrogen fixation and denitrification.

The model distinguishes two phytoplankton size classes (nanophytoplankton and diatoms) and two zooplankton size classes (microzooplankton and mesozooplankton). The $\mathrm{C} / \mathrm{N} / \mathrm{P}$ ratios are assumed constant for all species and fixed to the Redfield ratios. For phytoplankton, the prognostic variables are total biomass, iron, chlorophyll and silicon contents. The internal ratios of $\mathrm{Fe} / \mathrm{C}, \mathrm{Chl} / \mathrm{C}$ and $\mathrm{Si} / \mathrm{C}$ are predicted by the model. The only prognostic variable for zooplankton is total biomass. The bacterial pool is not modeled explicitly.

There are three non-living compartments for organic carbon in PISCES: small particulate organic carbon $\left(\mathrm{POC}_{s}\right)$, big particulate organic carbon $\left(\mathrm{POC}_{b}\right)$ and semi-labile dissolved organic carbon (DOC). The C/N/P composition of dissolved and particulate matter is also coupled to Redfield stochiometry. However, the iron, silicon and calcite pools of the particles are fully simulated and their ratios relative to organic carbon are allowed to vary. The production of calcite is assigned to nanophytoplankton as a function of temperature, saturation state, nutrient and light availability. The particulate detrital pools $\left(\mathrm{POC}_{s}, \mathrm{POC}_{b}\right.$, biogenic silica and calcite) are fuelled by mortality, aggregation from nanophytoplankton and diatoms, fecal pellet production and grazing. 
The model simulates dissolved inorganic carbon and total alkalinity. The carbon chemistry follows the OCMIP protocol (http://www.ipsl.jussieu.fr/OCMIP). A description of the model including model equations and parameters can be found as auxiliary material in Aumont and Bopp (2006).

\subsection{Calcium carbonate geochemistry}

The two-fold objective of this paper is (1) exploring the potential for aragonite dissolution to significantly contribute to shallow water $\mathrm{CaCO}_{3}$ dissolution and (2) producing a first evaluation of the impact of future rising atmospheric $\mathrm{CO}_{2}$ levels on aragonite production and dissolution. We adopt a geochemical approach to the question. This is justified by the limited observations available on aragonite production and dissolution in the ocean. Aragonite production and dissolution was implemented to PISCES in line with the general model structure and previous developments around the $\mathrm{CaCO}_{3}$ geochemistry in the model (Gehlen et al., 2007). This choice allows a straight-forward comparison between the model results of this study and output of PISCES in its calcite-only version (referred to as PISC/CAL) (Gehlen et al., 2007).

\subsubsection{Aragonite production}

In the modern ocean pelagos, cosmopolitan shelled pteropods are the main producers of aragonite (Lalli and Gilmer, 1989). Information on pteropod biogeography and ecology is scarce and largely summarized in Lalli and Gilmer (1989). Pteropods are mostly found in near-surface waters down to depths of about $200 \mathrm{~m}$. Only a few species inhabit deeper waters. We did not implement pteropods as a distinct functional type in the model, but assigned aragonite production to the corresponding zooplankton size class, mesozooplankton. Orr et al. (2005) report dissolution of pteropod aragonite shells in living organisms during exposure to water undersaturated with respect to aragonite. We might thus assume that the vertical distribution of pteropods across the water column is controlled by carbonate chemistry, e.g. that the organisms, and thus aragonite production, are restricted the water masses oversaturated with respect to aragonite.

We are unaware of published data on the response of calcification in pteropods to the saturation state. Previous studies on the effect of carbonate chemistry on the calcification in marine calcifiers focused on coccolithophores (e.g. Sciandra et al., 2003, Riebesell et al., 2000; Zondervan et al., 2001, 2002; Delille et al., 2005), foraminifera (e.g. Wolf-Gladrow et al., 1999; Bijma et al., 1999) and corals (e.g. Gattuso et al., 1998; Kleypas et al., 1999; Langdon et al., 2003, 2005). All these studies report a decrease in calcification with increasing $p \mathrm{CO}_{2}$ or decreasing saturation state. We expect that the calcification response will display a tolerance over a range of oversaturation typical of the natural variability experienced by the organism until a critical threshold is reached. Passing the threshold value, calcification is expected to decrease rapidly. The mathematical expression corresponds to a saturation curve, such as the Michaelis Menten equation derived for calcite production in Gehlen et al. (2007) from a compilation of experimental results for E. huxleyi. Studies of aragonite secreting warm water corals show different responses to decreasing saturation state dependent on species: Langdon (2005) reported a linear reduction in calcification whereas the study by Gattuso (1998) showed a decrease in aragonite production following a shape very similar to this Michaelis-Menten curve. It is uncertain whether planktonic pteropods react in the same way as corals. Thus, due to the lack of studies focusing on pteropods we chose to adopt the Michaelis-Menten curve fitted to the mesocosm experiment by Delille et al. (2005) also for aragonite production.

Aragonite production is expressed as the ratio of particulate inorganic $\mathrm{C}$ in the form of aragonite $\left(\mathrm{PIC}_{A}\right)$ to particulate organic $\mathrm{C}$ (POC), as a function of the saturation state of seawater and mesozooplankton biomass:

$$
\begin{aligned}
& \frac{\mathrm{PIC}_{A}}{\mathrm{POC}}=\text { factor }_{A} \times \mathrm{MESO} \times\left(\frac{\mathrm{PIC}_{A}}{\mathrm{POC}}\right)_{\text {max }} \\
& \times \frac{\left(\Omega_{A}-1\right)}{K_{\max }+\left(\Omega_{A}-1\right)} \text { for }\left(\Omega_{A}-1\right)>0,
\end{aligned}
$$

where: factor ${ }_{A}$, a scaling factor; MESO, mesozooplankton biomass $\left(\mathrm{mol} \mathrm{C}^{-1}\right)$; $\left(\mathrm{PIC}_{A} / \mathrm{POC}\right)_{\max }=0.8$, maximum ratio reached under optimal growth conditions; $K_{\max }=0.4$, with analogy to the half saturation constant.

$K_{\max }$ was chosen in order to obtain a curve with values of PIC/POC relatively constant for high saturation state values as typical for pre-industrial surface ocean waters, in line with the mesocosm experiment from Delille et al. (2005). The saturation index $\Omega_{A}=\left[\mathrm{Ca}^{2+}\right] \times\left(\left[\mathrm{CO}_{3}^{2-}\right] / K_{s p, A}\right)$ and $K_{s p, A}$ corresponds to the stoichiometric ion concentration product for aragonite after Mucci (1983). The scaling factor allows adjusting the partitioning of global carbonate production between calcite and aragonite to the range of published estimates. The pool of sinking aragonite particles is fuelled by mortality. The sum of calcite and aragonite production routed to the sinking particles is referred to as net $\mathrm{CaCO}_{3}$ production.

The change in concentration of mesozooplankton is given as:

$\delta \mathrm{MESO} / \delta \mathrm{t}=\Sigma$ grazing $_{\mathrm{N}}-$ respiration $_{-}$mortality.

The grazing term is written as:

$$
\begin{aligned}
& \operatorname{\Sigma grazing}_{N}=e^{m} \times\left(g^{\mathrm{MESO}}(P)+g^{\mathrm{MESO}}(D)\right. \\
& \left.+g^{\mathrm{MESO}_{(}}(Z)+g^{\mathrm{MESO}}(\mathrm{POC})\right) \times \mathrm{MESO},
\end{aligned}
$$

where: $e^{m}=0.33$, model growth efficiency; $g^{\mathrm{MESO}}=$ grazing rate for mesozooplankton on the various food sources $\left(\mathrm{d}^{-1}\right)$; 
$N=$ food sources: nanophytoplankton $(P)$, diatoms $(D)$, microzooplankton $(Z)$, and small and big particulate organic carbon (POC).

The parameterization for the grazing on multiple resources is shown as (e.g. Frost, 1987; Moloney and Field, 1991):

$$
g^{\mathrm{MESO}}(N)=g^{M} \times \frac{p_{N} \times N}{K_{G}+\sum_{I} p_{I} \times I}
$$

where: $g^{\operatorname{MESO}}(N)=$ grazing on individual food sources $N$; $g^{M}=0.7$, maximum grazing rate for mesozooplankton $\left(\mathrm{d}^{-1}\right)$; $p_{N}=$ preference mesozooplankton has for the food sources $N$; $K_{G}=20$, half-saturation constant for grazing $\left(\mu \mathrm{mol} \mathrm{Cl}^{-1}\right)$; $I=$ all the resources that mesozooplankton can graze on.

The equation implies that mesozooplankton always grazes on the most preferred prey. In addition to this concentrationdependent grazing, PISCES also accounts for flux-feeding. This type of grazing may be very important for the fate of particles in the water column below the euphotic zone (Dilling and Allredge, 2000; Stemmann et al., 2004). Fluxfeeding depends on the flux, the product of the concentration and of the sinking speed. Only the largest particles $\left(\mathrm{POC}_{b}\right)$ experience this type of grazing:

$g^{\mathrm{MESO}}\left(\mathrm{POC}_{b}\right)=g_{F F} \times w^{\mathrm{POC}_{b}} \times \mathrm{POC}_{b}$,

where: $g_{F F}=10^{3}$, maximum flux feeding rate $\left(\left(\mathrm{mmoll}^{-1}\right)^{-1}\right) ; \quad w^{\mathrm{POC} b}=$ sinking speed of big sinking particles $\left(\mathrm{m} \mathrm{d}^{-1}\right)$.

The second term in Eq. 2 is given as:

respiration $=r^{\mathrm{MESO}} \times \frac{\mathrm{MESO}}{K_{\mathrm{MESO}}+\mathrm{MESO}} \times \mathrm{MESO}$,

where: $r^{\mathrm{MESO}}=0.008$, excretion rate $\left(\mathrm{d}^{-1}\right) ; K_{\mathrm{MESO}}=0.1$, half-saturation constant for excretion $\left(\mu \mathrm{molCl}^{-1}\right)$.

Finally, the third term from Eq. 2 is written as:

mortality $=m^{\mathrm{MESO}} \times \mathrm{MESO}^{2}$,

where: $m^{\mathrm{MESO}}=0.03$, mesozoplankton mortality rate $\left(\left(\mu \mathrm{molCl}^{-1}\right)^{-1} \mathrm{~d}^{-1}\right)$.

The mortality term mimics predation, as most of the mortality of mesozooplankton is believed to be due to grazing by higher trophic levels. All terms in the equation driving the temporal evolution of mesozooplankton depend on temperature (Buitenhuis et al., 2005). For a further description of the parameterization of mesozooplankton please refer to Aumont and Bopp (2006).

In the PISCES standard version (Aumont and Bopp, 2006), large particles of organic carbon, as well as the detrital fractions biogenic opal and carbonate sink with a prescribed sinking speed that increases with depth from $50 \mathrm{~m} \mathrm{~d}^{-1}\left(0.05 \mathrm{~cm} \mathrm{~s}^{-1}\right)$ at the base of the mixed layer to $390 \mathrm{~m} \mathrm{~d}^{-1}\left(0.45 \mathrm{~cm} \mathrm{~s}^{-1}\right)$ at $5000 \mathrm{~m}$ depth. This parameterization accounts for the observed increase of sinking speed with depth (e.g. Berelson et al., 2002). The empirical relation for depth dependent sinking speed was calibrated using a model of aggregation/disaggregation resolving particle size (Gehlen et al., 2006). A compilation of different laboratory studies of sinking pteropods and empty shells was published by Lalli and Gilmer (1989). Among them, Byrne et al. (1984) measured the sinking speed of empty shells of the pteropod L. helicina to be equal to $1.0-1.4 \mathrm{~cm} \mathrm{~s}^{-1}$, about one order of magnitude higher than our modeled values. As discussed by Lalli and Gilmer (1989) however, these laboratory values are only approximations and do not take into account the slowing down by encountering temperature and density boundaries and by a reduction in weight owing to dissolution effects. Thus we expect the sinking speed in the real ocean to be slower. A lower sinking speed for carbonate particles is corroborated by a recent comprehensive study (Fischer and Karakas, 2008) suggesting average sinking rate values of carbonate particles equal to $51 \mathrm{~m} \mathrm{~d}^{-1}$ and $318 \mathrm{~m} \mathrm{~d}^{-1}$ in the upper and lower water column, respectively. Their values are well in range with other studies (e.g. Allredge and Silver 1988; Sawada 1988) and are nicely matched by our modeled values of sinking speed. The particles sink with a prescribed sinking speed according to:

$w=w_{\min }+\left(w_{\max }-w_{\min }\right) \times \max \left(0, \frac{z-z_{m}}{2000}\right)$,

where: $w_{\min }$, minimum sinking speed of $50 \mathrm{md}^{-1} ; w_{\max }$, maximum sinking speed at $2000 \mathrm{~m}$ below the mixed layer of $200 \mathrm{~m} \mathrm{~d}^{-1} ; z$, depth $(m) ; z_{m}$, mixed layer depth $(m)$.

The export flux is defined as the amount of sinking $\mathrm{CaCO}_{3}$ particles that falls through the depth horizon of $100 \mathrm{~m}$. There is no ocean-sediment interaction included in our model version. From the flux of $\mathrm{CaCO}_{3}$ reaching the deepest model boxes (=lower boundary) an alkalinity equivalent of totally $0.18 \mathrm{PgC}^{-1}$ corresponding to river input is removed (burial flux). The rest is re-dissolved instantaneously in the deepest grid cells. The model is strictly mass conserving.

\subsubsection{Aragonite dissolution}

Compared to the numerous studies addressing the dissolution kinetics of calcite (e.g. Morse and Berner, 1972; Berner and Morse, 1974; Morse, 1978; Honjo and Erez, 1978; Plummer et al., 1978; Keir, 1980; Walter and Morse, 1985; Arakaki and Mucci, 1995; Morse and Arvidson, 2002; Gehlen et al., 2005a, b; Morse et al., 2007), only a modest number of investigations focused on the dissolution behavior of aragonite (e.g. Morse et al., 1979; Keir, 1980; Busenberg and Plummer, 1986; Morse et al., 2007). These studies converge to assign a similar rate law to aragonite and calcite dissolution. The corresponding rate expression, $R$, for $\mathrm{CaCO}_{3}$ dissolution writes: 
$R=k \times\left(1-\Omega_{A}\right)^{n}$ for $\left(\Omega_{A}-1\right)<0$

where: $k$, dissolution rate constant, $\left(\mathrm{d}^{-1}\right) ; n$, dimensionless reaction order.

The dissolution of $\mathrm{CaCO}_{3}$ is in general described as a higher order reaction with estimates of $\mathrm{n}$ ranging from 2.3 to 4.5 (e.g. Morse and Arvidson, 2002). Due to the limited information available specifically on aragonite dissolution, we adopted the same rate description and reaction rate constant as for calcite in Gehlen et al. (2007). Aragonite dissolution is thus described as a first order reaction $(n=1)$ with respect to undersaturation with a dissolution rate constant of $10.9 \mathrm{~d}^{-1}$. The latter was derived from the evolution with depth of $\mathrm{CaCO}_{3}$ fluxes recorded in traps deployed below $1000 \mathrm{~m}$ (Gehlen et al., 2007). 11 stations were selected, for which mean annual fluxes were reported from at least two different deployment depths from a comprehensive study on particle fluxes (Dittert et al., 2005). The fraction of $\mathrm{CaCO}_{3}$ lost to dissolution was calculated as the difference in $\mathrm{CaCO}_{3}$ concentrations between the respective upper and lower traps. A linear dependency of $\mathrm{CaCO}_{3}$ dissolution on underestimation was adopted, as supported by Hales (2003). The reaction rate constant $k$ was next calculated based on the fraction lost to dissolution, the concentration of calcite particles and the saturation state with respect to calcite. The values of $n$ and $k$ may not be changed separately; as they combined fit the dissolution fluxes from this study. For a detailed description of this calculation, please refer to Gehlen et al. (2007). The derivation by Keir (1980) of similar reaction rate constants for pteropods and untreated E. huxleyi supports our choice of using the same dissolution rate expressions for aragonite.

The quantity of $\mathrm{CaCO}_{3}$ particles that re-dissolves in the deepest grid cells of the model is not included in our definition of pelagic $\mathrm{CaCO}_{3}$ dissolution. The ratio between pelagic dissolution and net production is here denoted as relative $\mathrm{CaCO}_{3}$ dissolution.

\section{Model simulations}

The physical fields that are used to force PISCES are based on a climatological simulation with the ORCA2 global ocean model configuration of OPA version 8.2 (Madec et al., 1998). The mean horizontal resolution of the model is approximately $2^{\circ}$ by $2^{\circ} \cos$ latitude and the meridional resolution is enhanced to $0.5^{\circ}$ at the equator. The model has 30 vertical levels; with an increment that increases from $10 \mathrm{~m}$ at the surface to $500 \mathrm{~m}$ at depth (12 levels are located in the first $125 \mathrm{~m}$ ). The physical/dynamical simulation with OPA employs climatological atmospheric forcing from various data sets. These include NCEP/NCAR $2 \mathrm{~m}$ atmospheric temperature (averaged between 1948 and 2003) and relative humidity, ISCCP total cloudiness (averaged between 1983 and 2001), precipitation (averaged between 1979 and 2001), weekly wind stress based on ERS and TAO observations and $\begin{array}{cc}\text { Aragonite saturation depth } & \text { Depth } \\ \text { (m) }\end{array}$

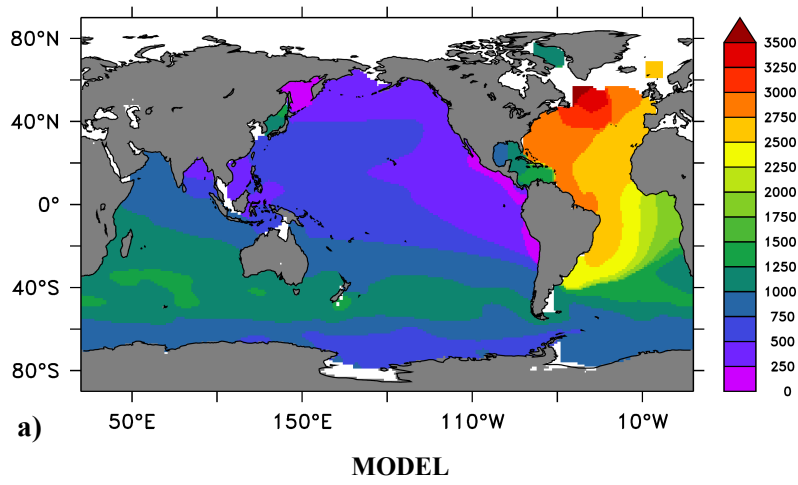

Depth

(m)

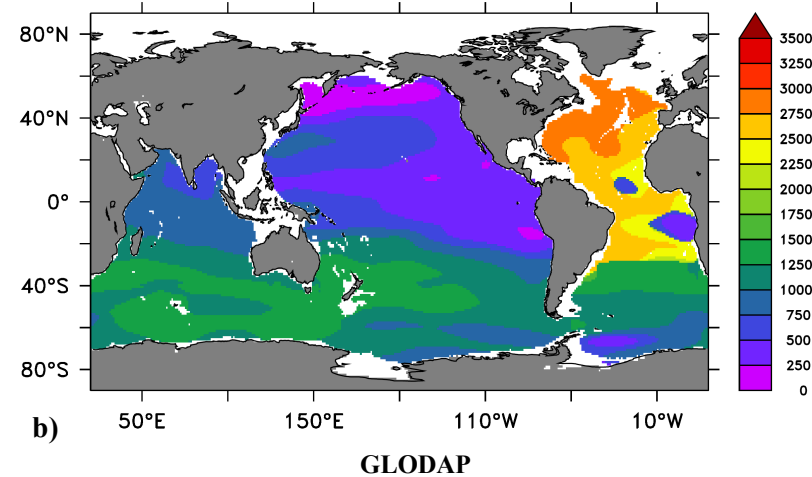

Fig. 1. Depth of aragonite saturation horizon: (a) model output, (b) recalculated from GLODAP (Key et al., 2004).

creates a representation of ocean circulation/mixing that is forced by observational climatologies. Please see Aumont and Bopp (2006) for more details and the associated references.

Model alkalinity field was initialized with the global mean alkalinity value from Goyet et al. (2000). The new parameterizations of aragonite production and dissolution were implemented with aragonite production accounting for $1 / 3$ of the total net $\mathrm{CaCO}_{3}$ production. In order to obtain the approximate 1:2 relationship between aragonite and calcite, the scaling factor for aragonite was set equal to 0.05 and the one for calcite equal to 0.3 . This is in the upper end of the range of most estimates and permits the identification of an approximate upper limit of which aragonite may contribute to the estimated shallow depth $\mathrm{CaCO}_{3}$ dissolution. The consequent changes in the $\mathrm{CaCO}_{3}$ cycle call for a long spin-up; hence the model was integrated over 5000 years using the degradation-integration tool DEGINT (Aumont et al., 1998) to reach quasi-equilibrium. The tracer output was used to re-initialize the PISCES model at the original resolution $\left(2 \times 2^{\circ} \cos\right.$ (latitude), 31 vertical levels) and the model was then integrated over 300 years using a 
Table 1. The carbonate cycle in PISCES: Comparison between model output and data in $\mathrm{Pg} \mathrm{CaCO}_{3}-\mathrm{Cy}^{-1}$. PISC/CAL=results from an equivalent model study without aragonite (Gehlen et al., 2007). The lower boundary represents the deepest model grid boxes.

\begin{tabular}{|c|c|c|c|c|}
\hline Process & Present study & PISC /CAL & Data & Data references \\
\hline \multicolumn{5}{|l|}{ Source } \\
\hline Net $\mathrm{CaCO}_{3}$ production & 0.9 & 0.8 & $0.8-1.6$ & $\begin{array}{l}\text { Iglesias-Rodriguez et al. (2002), } \\
\text { Lee (2001), Jin et al. (2006), } \\
\text { Berelson et al. (2007) }\end{array}$ \\
\hline \multicolumn{5}{|l|}{ Sinks } \\
\hline Total pelagic $\mathrm{CaCO}_{3}$ dissolution & 0.5 & 0.5 & $\begin{array}{c}0.5 \pm 0.2 \\
1.0 \pm 0.5 \\
(>1500 \mathrm{~m})\end{array}$ & $\begin{array}{l}\text { Feely et al. (2004), } \\
\text { Berelson et al. (2007) }\end{array}$ \\
\hline $\mathrm{CaCO}_{3}$ flux at lower boundary & 0.3 & 0.3 & - & - \\
\hline $\mathrm{CaCO}_{3}$ burial flux & - & - & 0.3 & Feely et al. (2004) \\
\hline \multicolumn{5}{|l|}{ Related fluxes } \\
\hline Export flux $100 \mathrm{~m}$ & 0.6 & 0.6 & 0.6 & $\begin{array}{l}\text { Sarmiento et al. (2002), } \\
\text { Berelson et al. (2007) }\end{array}$ \\
\hline $\begin{array}{l}\mathrm{CaCO}_{3} \text { dissolution } 0-1000 \mathrm{~m} \\
\left(\% \text { of tot. } \mathrm{CaCO}_{3} \text { production) }\right.\end{array}$ & $\begin{array}{c}0.1 \\
(14 \%)\end{array}$ & $\begin{array}{c}0.02 \\
(2.5 \%)\end{array}$ & $(60-80 \%)$ & $\begin{array}{l}\text { (Milliman and Droxler, 1996) }\end{array}$ \\
\hline $\begin{array}{l}\mathrm{CaCO}_{3} \text { dissolution } 0-2000 \mathrm{~m} \\
\left(\% \text { of tot. } \mathrm{CaCO}_{3} \text { dissolution) }\right.\end{array}$ & $\begin{array}{c}0.3 \\
(58 \%)\end{array}$ & $\begin{array}{c}0.2 \\
(34 \%)\end{array}$ & $(\geq 60 \%)$ & (Feely et al., 2004) \\
\hline
\end{tabular}

constant climatological ocean circulation field without interannual variability before reaching final equilibrium. Atmospheric $\mathrm{CO}_{2}$ was all the time kept constant and equal to 278 parts per million (ppm).

To study the effect of rising $p \mathrm{CO}_{2}$ on the carbonate cycle, a model experiment with two different atmospheric $\mathrm{CO}_{2}$ scenarios were performed: one with constant pre-industrial $\mathrm{CO}_{2}$ concentrations and one with prescribed increasing atmospheric $\mathrm{CO}_{2}$ concentrations. The prescribed increase of atmospheric $\mathrm{CO}_{2}$ starts with a pre-industrial value of 286.2 ppm and follows the historical development (IPCC SRES 20C3M) for the period from 1861-1999 and the A2 scenario (IPCC SRES A2) from 2000-2100. The resulting atmospheric $p \mathrm{CO}_{2}$ values for the years 2000 and 2100 are $367 \mathrm{ppm}$ and $827 \mathrm{ppm}$, respectively. For all simulations the model was forced with a constant climatological ocean circulation field without interannual variability.

\section{Results and discussion}

\subsection{Model initial state}

\subsubsection{Aragonite saturation state}

Simulated aragonite saturation horizons are compared to the pre-industrial saturation depth values from the Global Ocean Data Analysis Project (GLODAP) (Key et al., 2004), and presented in Fig. 1. Except from the North Atlantic, where the modeled aragonite saturation horizon is located slightly deeper than the GLODAP saturation horizon, there is a very good match between model and observations. The modeled aragonite saturation horizon follows the estimated saturation depth characteristics: it is deepest in the Atlantic, and shoals through the Indian to the Pacific Oceans following the water circulation along the deep conveyor belt, where the water masses get more and more enriched in DIC the older they get due to the remineralization of organic matter.

\subsection{2 $\mathrm{CaCO}_{3}$ sources and sinks}

Table 1 compares global pelagic pre-industrial $\mathrm{CaCO}_{3}$ production, export and dissolution obtained from the present model study, from a similar study (PISC/CAL) which only considered calcite (Gehlen et al., 2007) and from observation-based estimates. The final total net calcification in the present study at the end of the spin-up $\left(0.87 \mathrm{PgC}^{-1}\right)$ is slightly higher than the one in PISC/CAL $\left(0.79 \mathrm{PgC}^{-1}\right)$. Both values lay at the lower end of the range of estimates. The total pelagic $\mathrm{CaCO}_{3}$ dissolution predicted by the model is $0.55 \mathrm{PgCy}^{-1}$, whereas the value obtained with the model version PISC/CAL was $0.48 \mathrm{PgCy}^{-1}$. The results from both model versions closely match the estimate of $0.5 \pm 0.2 \mathrm{PgC}^{-1}$ published by Feely et al. (2004). They are lower than the best estimate from Berelson et al. (2007), but still consistent with their uncertainty range (Table 1). 
Finally the budget is closed by the sinking $\mathrm{CaCO}_{3}$ particles that reach the model lower boundary. This flux does not correspond to the burial flux reported in literature and may not be directly compared to observations.

The modeled $\mathrm{CaCO}_{3}$ export from the upper $100 \mathrm{~m}$ matches well the result by Sarmiento et al. (2002) of $0.6 \mathrm{PgC}^{-1}$. The export is smaller than the net production due to a quantity of $\mathrm{CaCO}_{3}$ production below, and a small amount of dissolution above, $100 \mathrm{~m}$.

\subsubsection{Calcite and aragonite production}

The different environmental controls on calcite and aragonite production in the model lead to different global distributions of calcite and aragonite production (Fig. 2). For the calcite production (Fig. 2a), the spatial variability is well reproduced by the model: low values in central ocean gyres, high values in upwelling zones of the eastern boundary currents, the Arabian Sea and the equatorial Pacific and Atlantic. Consistent with Milliman (1993), the model also predicts increased rates of calcite productivity in subpolar waters. Vertically integrated rates of calcite production range between $0.02 \mathrm{mgC} \mathrm{m}^{-2} \mathrm{~d}^{-1}$ in central ocean gyres to $78 \mathrm{mgC} \mathrm{m}^{-2} \mathrm{~d}^{-1}$ reached in localized hot spots as the Gulf of Thailand and south of the Gulf of Guinea. Milliman (1993) reports typical values for open ocean $\mathrm{CaCO}_{3}$ production spanning from 0.4 to $20 \mathrm{mgC} \mathrm{m}^{-2} \mathrm{~d}^{-1}$, where the contribution of aragonite is explicitly excluded. A total open ocean $\mathrm{CaCO}_{3}$ production of $6.9-7.9 \mathrm{mgC} \mathrm{m}^{-2} \mathrm{~d}^{-1}$ was calculated by Morse and MacKenzie (1990). The model yields an average total $\mathrm{CaCO}_{3}$ production of $6.7 \mathrm{mgC} \mathrm{m}^{-2} \mathrm{~d}^{-1}$.

The distribution of aragonite production in the model follows ocean productivity with maximum values in areas where the latter is high (e.g. upwelling zones, subpolar waters) (Fig. 2b). This pattern reflects the occurrence of mesozooplankton which is tightly coupled to the availability of food. The model simulates an average aragonite production of $2.4 \mathrm{mgC} \mathrm{m}^{-2} \mathrm{~d}^{-1}$. Fabry $(1989,1990)$ reports estimates ranging from $0.25 \mathrm{mgC} \mathrm{m}^{-2} \mathrm{~d}^{-1}$ in the Central Pacific to $0.83 \mathrm{mgC} \mathrm{m}^{-2} \mathrm{~d}^{-1}$ in the equatorial $\mathrm{Pa}$ cific. Betzer et al. (1984) observed an aragonite flux of 2.3$4.9 \mathrm{mgC} \mathrm{m}^{-2} \mathrm{~d}^{-1}$ at $100 \mathrm{~m}$ in the North Pacific, where the samples were taken above the aragonite saturation horizon and living pteropods were excluded (Betzer et al., 1984). Of the total net $\mathrm{CaCO}_{3}$ production, aragonite production in the model $\left(0.30 \mathrm{PgC}^{-1}\right)$ amounts to $35 \%$.

While the model predicts aragonite production in high latitudes of the right order of magnitude, it overestimates the production in equatorial areas compared to Fabry (1990). About $40 \%$ of the modeled total aragonite production takes place between $0^{\circ}$ and $20^{\circ}$ while only $10 \%$ occurs at latitudes greater than $40^{\circ}$. Most of the aragonite production is suggested to take place in subpolar and polar areas (Lalli and Gilmer, 1989). This indicates a possible overestimation by our model of the aragonite production in the equatorial areas,
Calcite production, vert. integrated

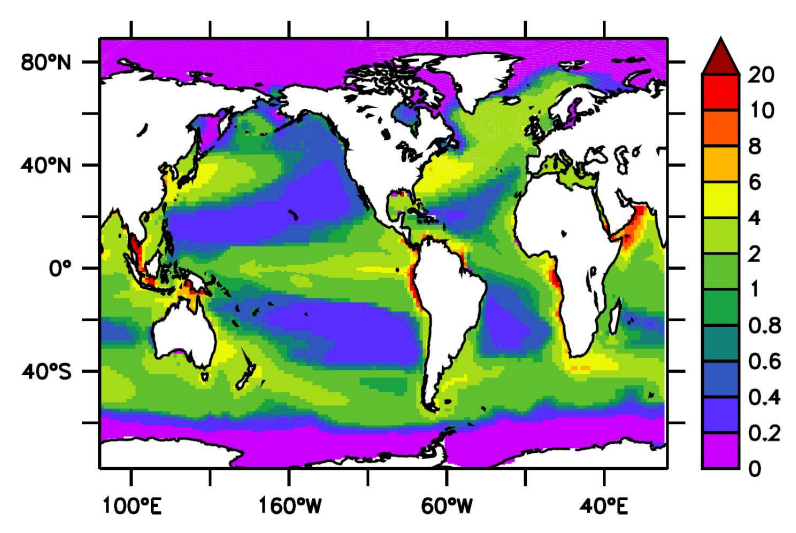

a)

$$
\left(\mathrm{gC} \mathrm{m} \mathrm{s}^{-1}\right)
$$

Aragonite production, vert. integrated

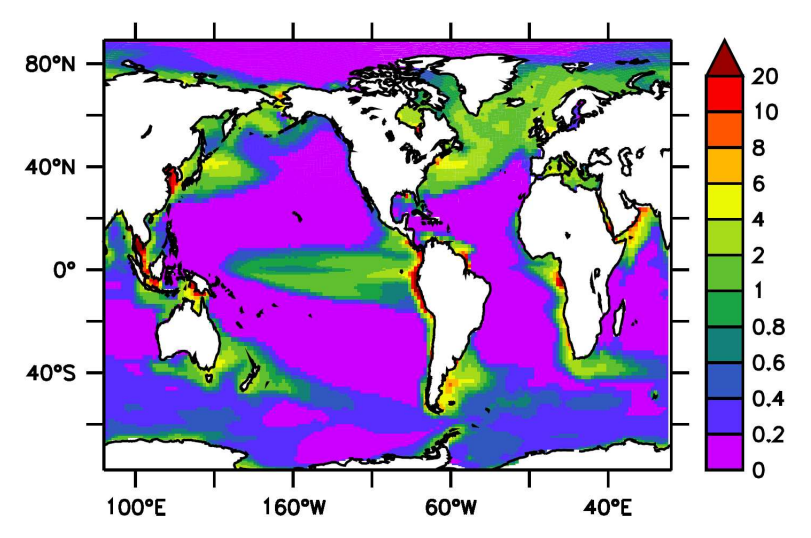

b)

$$
\left(\mathrm{gC} \mathrm{m}^{-2} \mathrm{~s}^{-1}\right)
$$

Total $\mathrm{CaCO}_{3}$ production, vert. integrated

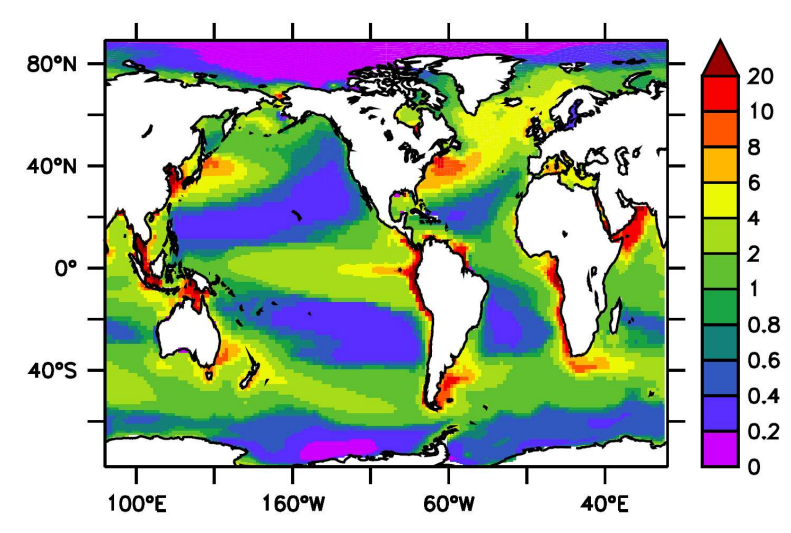

c)

$$
\left(\mathrm{gC} \mathrm{m}^{-2} \mathrm{~s}^{-1}\right)
$$

Fig. 2. Production of (a) calcite, (b) aragonite and (c) total $\mathrm{CaCO}_{3}$ in $\mathrm{gC} \mathrm{m}^{-2} \mathrm{~s}^{-1}$, integrated over depth. 


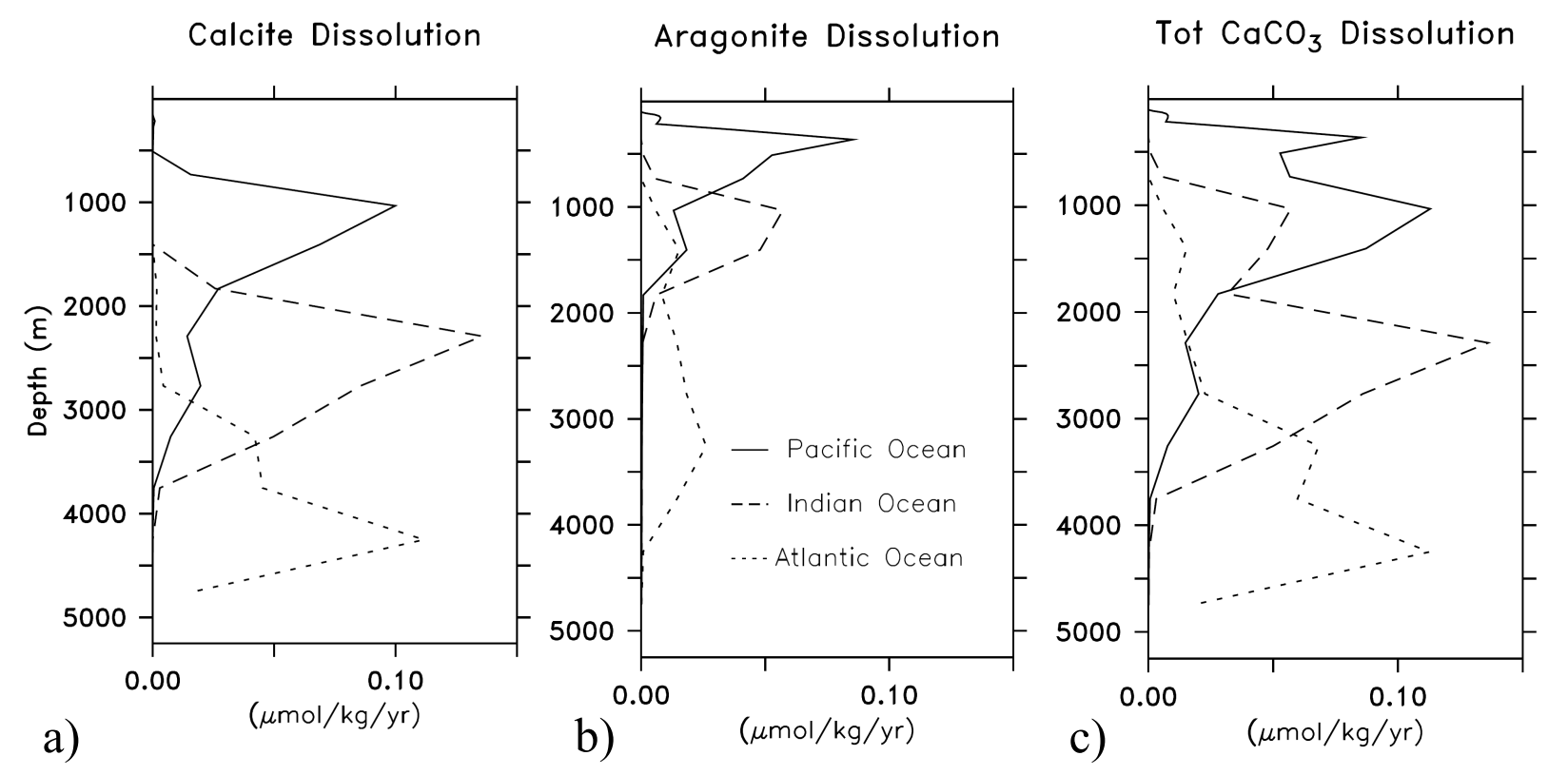

Fig. 3. Average pelagic (a) calcite, (b) aragonite and (c) $\mathrm{CaCO}_{3}$ dissolution rates in the Atlantic, Pacific and Indian Ocean basin.

perhaps in combination with an underestimation in higher latitudes. The latter is supported by an underestimation of the modeled mesozooplankton biomass in ocean gyres and subpolar areas compared to observations compiled by Buitenhuis et al. (2006), especially in the north Pacific. The low mesozooplankton biomass in ocean gyres in turn reflects the tendency of the model to underpredict ocean productivity in these regions (Gehlen et al., 2006). However, in agreement with observations, the model presents higher aragonite production in the western North and eastern equatorial Pacific and lower values in the Central Pacific, which is consistent with the mesozooplankton distribution in these areas (Fabry, 1990; Buitenhuis et al., 2006).

\subsubsection{Calcite and aragonite dissolution}

Although total $\mathrm{CaCO}_{3}$ dissolution in both the present model version and in PISC/CAL match literature estimates, we see an essential difference between the two model versions when studying the vertical distribution of the $\mathrm{CaCO}_{3}$ dissolution in the water column. The profiles of $\mathrm{CaCO}_{3}$ water column dissolution for the Atlantic, Pacific and Indian Ocean (Fig. 3) show how the water column dissolution of aragonite (Fig. 3b) starts at distinctly shallower depths than dissolution of calcite (Fig. 3a), which is directly related to the shallower location of the aragonite saturation horizon compared to the calcite saturation horizon in the three oceans (e.g. Broecker and Takahashi, 1978; Feely and Chen, 1982; Feely et al. 2004). It results in shallow depth $\mathrm{CaCO}_{3}$ dissolution in the Pacific Ocean, mid-depth water dissolution in the Indian Ocean and deep water dissolution in the Atlantic Ocean basin (Fig. 3c).
Maxima in open water aragonite dissolution are at $400 \mathrm{~m}$, $1000 \mathrm{~m}$, and $3200 \mathrm{~m}$ depth in the Pacific, Indian and Atlantic, respectively, while the basin-mean peak rates for water column calcite dissolution are simulated at $1000 \mathrm{~m}, 2300 \mathrm{~m}$ and $4200 \mathrm{~m}$.

The simulated total amount of $\mathrm{CaCO}_{3}$ that dissolves in the upper $1000 \mathrm{~m}$ of the pelagic ocean equals $0.12 \mathrm{PgC}^{-1}$, whereas $0.32 \mathrm{PgC}^{-1}$ dissolves in the upper $2000 \mathrm{~m}(\mathrm{Ta}-$ ble 1). Milliman and Droxler (1996) compared the dissolution in the upper $1000 \mathrm{~m}$ to the total $\mathrm{CaCO}_{3}$ production and reported that between $60-80 \%$ of the total production dissolved at shallow depths. Feely et al. used the $2000 \mathrm{~m}$ horizon to separate the upper and lower part of the water column and compared the dissolution in the upper part to the total water column dissolution. Combining the sediment trap flux of $\mathrm{CaCO}_{3}$ at $2000 \mathrm{~m}\left(0.41 \mathrm{PgCy}^{-1}\right)$ and the $\mathrm{CaCO}_{3}$ accumulation in continental shelf sediments $\left(0.13-0.17 \mathrm{PgC}^{-1}\right)$, they conclude that up to $60 \%$ or more of the total dissolution occurs in the water column or sediments in the upper 2000 $\mathrm{m}$, with most of the $\mathrm{CaCO}_{3}$ dissolving before it reaches the sediment-water interface. Whereas our model yields a dissolution flux in the upper $1000 \mathrm{~m}$ accounting for only $14 \%$ of the total $\mathrm{CaCO}_{3}$ produced, it simulates a dissolution flux above $2000 \mathrm{~m}$ corresponding to $58 \%$ of the total pelagic water column $\mathrm{CaCO}_{3}$ dissolution, comparable to the findings of Feely et al. (2004). In contrast, the equivalent percentages for the model version PISC/CAL which only considered calcite are no more than 2.5 and $38 \%$, respectively.

Our modeled aragonite contribution to the shallow depth $\mathrm{CaCO}_{3}$ dissolution represents an upper limit estimate. Thus, the discrepancy between model output and estimates 
a) Mean omega aragonite

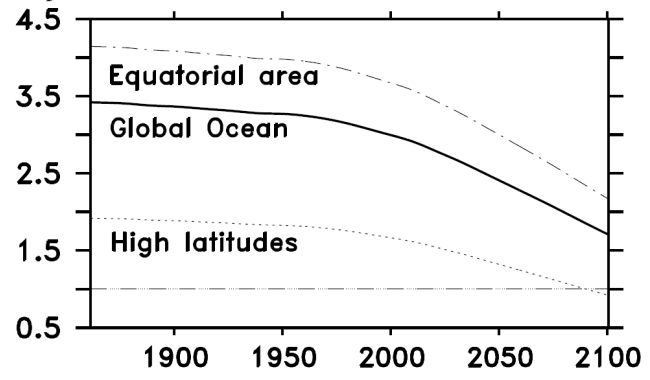

C)

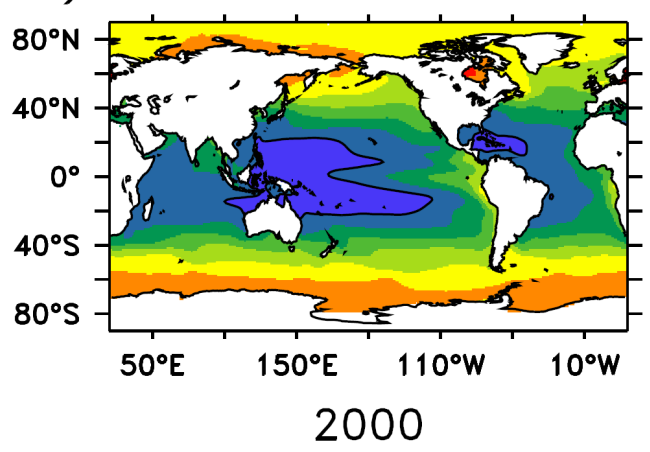

e)

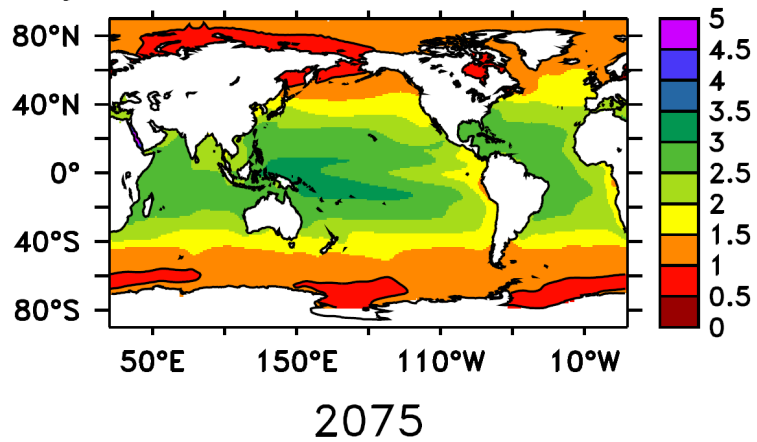

b)

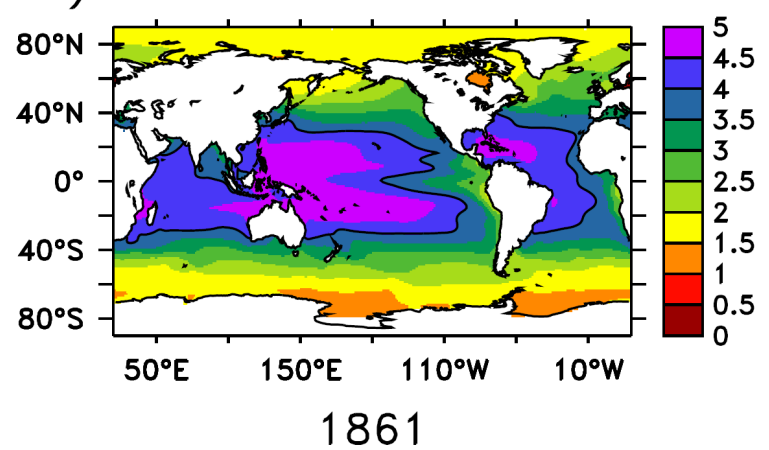

d)

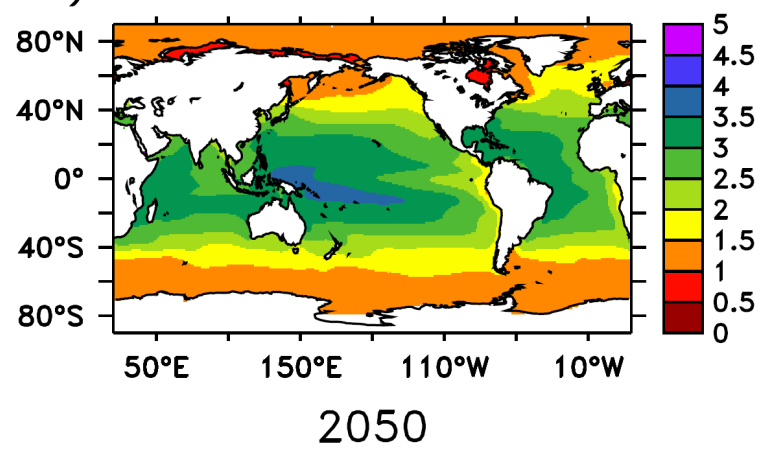

f)

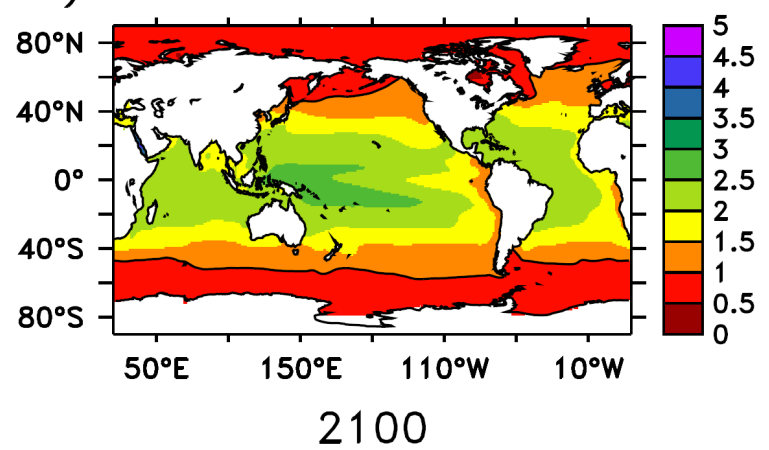

Fig. 4. Saturation state with respect to aragonite of surface waters $(0-100 \mathrm{~m})$ : (a) timeseries of mean $\Omega_{a}$ for the global ocean, the equatorial area and for high latitudes, and maps in year (b) 1861, (c) 2000, (d) 2050, (e) 2075 and (f) 2100. Solid curves indicate $\Omega_{a}=4$ for year 1861 and 2000 and $\Omega_{a}=1$ for year 2050, 2075 and 2100.

(Milliman and Droxler, 1996) in the upper $1000 \mathrm{~m}$ supports the findings that additional mechanisms (e.g. Friis et al., 2007, Antia et al., 2008) are needed in order to explain the overall estimated loss of $\mathrm{CaCO}_{3}$ or excess of alkalinity in the upper part of the water column. However, our results maintain that the underestimation of the modeled $\mathrm{CaCO}_{3}$ dissolution in the upper $0-2000 \mathrm{~m}$ in PISC/CAL may to a great extent result from an exclusion of aragonite in the PISCES model as proposed by Gehlen et al. (2007).
The increased shallow depth dissolution obtained by implementing aragonite yields support to the hypothesis that high dissolution fluxes at depths above $2000 \mathrm{~m}$ may largely be attributed to more soluble $\mathrm{CaCO}_{3}$ phases like aragonite (Iglesias-Rodriguez et al., 2002; Kleypas et al., 2006). Furthermore, the vertical distribution of the $\mathrm{CaCO}_{3}$ dissolution fluxes in the present model version is considerably improved compared to the PISC/CAL version. 
Table 2. Summary of pelagic calcite and aragonite production, sinking fluxes, dissolution and relative dissolution for the years 1861,2000 and 2100 (averaged over 10 years and drift corrected) in $\mathrm{PgCy}^{-1}$. Changes between pre-industrial times and at the end of the scenario are given in $\%$.

\begin{tabular}{|c|c|c|c|c|}
\hline Process & $\begin{array}{c}\text { Pre-ind } \\
(1861-1870)\end{array}$ & $\begin{array}{c}\text { Today } \\
(1996-2005)\end{array}$ & $\begin{array}{c}\text { Future } \\
(2091-2100)\end{array}$ & $\begin{array}{c}\text { Changes between } \\
\text { Pre-ind and Future }(\%)\end{array}$ \\
\hline \multicolumn{5}{|l|}{ Production } \\
\hline Net calcite production & 0.57 & 0.56 & 0.49 & -13 \\
\hline Net aragonite production & 0.31 & 0.30 & 0.22 & -29 \\
\hline Net $\mathrm{CaCO}_{3}$ production & 0.87 & 0.85 & 0.71 & -19 \\
\hline \multicolumn{5}{|l|}{ Export $(100 \mathrm{~m})$} \\
\hline Calcite export & 0.41 & 0.41 & 0.36 & -13 \\
\hline Aragonite export & 0.22 & 0.21 & 0.13 & -41 \\
\hline $\mathrm{CaCO}_{3}$ export & 0.63 & 0.62 & 0.49 & -23 \\
\hline \multicolumn{5}{|l|}{ Dissolution, total } \\
\hline Calcite dissolution & 0.38 & 0.37 & 0.35 & -7 \\
\hline Aragonite dissolution & 0.18 & 0.18 & 0.16 & -15 \\
\hline $\mathrm{CaCO}_{3}$ dissolution & 0.56 & 0.55 & 0.50 & -10 \\
\hline \multicolumn{5}{|l|}{ Relative dissolution, total } \\
\hline Calcite dissolution/net prod. (\%) & 67 & 67 & 71 & 4 \\
\hline Aragonite dissolution/net prod. (\%) & 60 & 62 & 72 & 12 \\
\hline $\mathrm{CaCO}_{3}$ dissolution/net prod. $(\%)$ & 64 & 65 & 71 & 7 \\
\hline \multicolumn{5}{|l|}{ Dissolution, 0-2000 m } \\
\hline Calcite dissolution & 0.18 & 0.18 & 0.20 & 12 \\
\hline Aragonite dissolution & 0.15 & 0.15 & 0.14 & -6 \\
\hline $\mathrm{CaCO}_{3}$ dissolution & 0.34 & 0.34 & 0.35 & 4 \\
\hline \multicolumn{5}{|l|}{ Relative dissolution, 0-2000 m } \\
\hline Calcite dissolution/net prod. (\%) & 32 & 33 & 42 & 10 \\
\hline Aragonite dissolution/net prod. (\%) & 50 & 53 & 66 & 16 \\
\hline $\mathrm{CaCO}_{3}$ dissolution/net prod. (\%) & 38 & 40 & 49 & 11 \\
\hline
\end{tabular}

\subsection{Transient simulation}

Projections of future changes of the $\mathrm{CaCO}_{3}$ budget with increasing atmospheric $\mathrm{CO}_{2}$ will next be presented and discussed. Figure 4 presents a) timeseries of the mean saturation state of surface waters with respect to aragonite and corresponding maps for year b) 1861 , c) 2000 , d) 2050, e) 2075 and f) 2100 for the SRES A2 scenario. In addition to the Global Ocean, results are shown for two critical areas: 1) the high latitudes or polar and subpolar regions (here defined as the area $>40^{\circ} \mathrm{S}$ and $>40^{\circ} \mathrm{N}$ ) where the largest change in saturation state occurs, and 2) the equatorial area (here restricted within $20^{\circ} \mathrm{S}-20^{\circ} \mathrm{N}$ ) which include important upwelling areas with high calcification rates. Time series of a) and b) net calcite and aragonite production, c) and d) calcite and aragonite dissolution and e) and f) relative calcite and aragonite dissolution are shown in Fig 5. Model results for $\mathrm{CaCO}_{3}$ production, export, sinking fluxes, dissolution and relative dissolution for year 1861, 2000 and 2100 are summarized in Table 2.

The mean global saturation state of surface ocean waters $(0-100 \mathrm{~m})$ with respect to aragonite decreases from $\Omega_{a}>3.5$ in year 1861 to less than 2 in year 2100 (Fig. 4a). In the equatorial area the mean saturation state decreases rapidly from $\Omega_{a}>4$ to $\Omega_{a}=2$ at the end of the scenario, whereas at high latitudes where the saturation state is already very low, it reaches values below 1 before year 2100. According to our parameterization, calcification may occur everywhere where $\Omega_{a}>1$. Maps of $\Omega_{a}$ averaged over the top $100 \mathrm{~m}$ of the water column (Fig. 4b-f) show that in year 1861 the criteria for aragonite production is met everywhere across the global surface ocean. In year 2000 the areas of $\Omega_{a}>4$ are somewhat reduced, while in year 2050 such areas do no longer exist and small regions of the surface water in the Arctic Ocean are now already projected to be undersaturated with respect to aragonite for the SRES A2 scenario. Following the 
decreasing saturation values, in year 2075 large areas of both the Arctic and the Southern Ocean are undersaturated with respect to aragonite, whereas in year 2100 , compared to preindustrial times, the conditions for calcification have altered dramatically. Most of the Southern and the Arctic Ocean experience at this time $\Omega_{a}<1$, indicating unfavorable conditions for aragonite production and matching results of Orr et al. (2005) for the Southern Ocean and of Steinacher (2007) for the Arctic.

The change in saturation state with respect to calcite follows a similar pattern (see Gehlen et al., 2007), however as the saturation horizon of aragonite is located shallower in the water column than the one of calcite (e.g. Broecker and Takahashi, 1978; Feely and Chen, 1982) the surface waters get undersaturated with respect to aragonite at a much earlier stage.

The predicted reduction in saturation state is further reflected in the modeled production and dissolution rates of $\mathrm{CaCO}_{3}$ (Fig. 5 and Table 2). Both calcite and aragonite calcification rates have decreased considerably at the end of the SRES A2 scenario (Fig. 5a). While the reduction in production rates is insignificant during the historical period up to year 2000, it is large after year 2050. By this year, Orr et al. (2005) projected that the Southern Ocean surface waters would begin to become undersaturated with respect to aragonite. Hoegh-Guldberg et al. (2007) indicate a threshold for major changes to coral reefs to be at about $480 \mathrm{ppm}$, which according to the SRES A2 scenario represents year 2040. For calcite the total global production rate per year has decreased by $13 \%$ at the end of the scenario, from 0.57 (pre-industrial times.) to $0.49 \mathrm{PgC}^{-1}$ (year 2100). For aragonite the corresponding reduction in global production rate is of considerably $29 \%$, i.e. of almost $1 / 3$ since pre-industrial times, with global aragonite production decreasing from 0.31 to $0.22 \mathrm{PgCy}^{-1}$. The modeled decrease in total $\mathrm{CaCO}_{3}$ production is $19 \%$. The calcite and aragonite export flux at $100 \mathrm{~m}$ decreases by 13 and $41 \%$, respectively, providing a decrease in total $\mathrm{CaCO}_{3}$ export of $23 \%$.

Gehlen et al. (2007) performed an experiment according to the standard CMIP scenario of atmospheric $p \mathrm{CO}_{2}$ increasing at a rate of $1 \%$ per year from 286 to 1144 ppm over a 140 year time-period. They simulated a decrease in $\mathrm{CaCO}_{3}$ production of $27 \%$ at the end of their scenario, where the initial production was $0.8 \mathrm{PgCy}^{-1}$. The export was reduced by $29 \%$. Their final atmospheric $\mathrm{CO}_{2}$ concentration was however 4 times the pre-industrial concentration, while with the SRES A2 scenario used in the present study the atmospheric value of $\mathrm{CO}_{2}$ in year 2100 is closer to 3 times the pre-industrial value. On the other hand, the duration of their scenario was shorter and the annual rate of $p \mathrm{CO}_{2}$ was higher. At 3 times the pre-industrial value a reduction in calcification of approximately $15 \%$ was predicted with PISC/CAL, not far from our predicted reduction in calcite production of $13 \%$ with the present model version.
In addition to the decrease in pelagic carbonate production with increasing $\mathrm{CO}_{2}$ concentrations, the modeled amount of pelagic calcite and aragonite dissolution decreases (Fig. 5d). The fact that this occurs, although one might expect higher dissolution in more acidic waters, can be explained by the reduced abundance of particulate $\mathrm{CaCO}_{3}$ due to lower $\mathrm{CaCO}_{3}$ productivity. The relative amount of pelagic $\mathrm{CaCO}_{3}$ dissolution, however, expressed as the ratio of calcite and aragonite dissolution versus the respective rate of production (dissolution/production) in percent, is increasing (Fig. 5e). A slight increase from 67 to $71 \%$ of calcite material is dissolved in the water column, whereas for aragonite the ratio increases by $12 \%$, from 60 to $72 \%$, i.e. 3 times more than for calcite. This leads to a total increase in relative $\mathrm{CaCO}_{3}$ dissolution from 64 to $71 \%$. The reason why the calcite dissolution to net production ratio is higher than the equivalent ratio for aragonite is probably due to the fact that a larger fraction of the aragonite production occurs in areas with deep saturation horizons, where very little or no dissolution may occur, than of the calcite production. $30 \%$ of the total pelagic aragonite production takes place in the Atlantic Ocean where the saturation horizon is deepest, compared to $27 \%$ of the total calcite production. In the north Atlantic only, $19 \%$ of the total aragonite is produced, whereas $16 \%$ of the total calcite production takes place in this area. Due to the gradually lower saturation state value in surface waters, the predicted increase in relative calcite and especially aragonite dissolution is highest in the upper part of the water column. In the upper $2000 \mathrm{~m}$ the relative dissolution of calcite, aragonite and total $\mathrm{CaCO}_{3}$ increase by 10,16 and $11 \%$, respectively (Table 2).

As the waters within year 2100 mainly become undersaturated with respect to calcite and aragonite in the high latitudes, we would expect the largest effects on $\mathrm{CaCO}_{3}$ production in this area. In fact, the calcite production in the high latitudes is reduced by as much as $24 \%$, while the aragonite production is reduced dramatically by $65 \%$ (from 0.03 to $0.009 \mathrm{PgC}^{-1}$ ). The relative calcite dissolution has increased by $4 \%$, whereas the relative aragonite dissolution has experienced a drastic increase of $72 \%$, from 41 to $113 \%$. The latter value implies that in the end of the SRES A2 scenario, more aragonite is actually dissolved than produced in this area, indicating transport of some aragonite particles from lower to higher latitudes. It may also in part be due to a transient behaviour; if the production decreases while the stock of particles still reflects the previous higher production rate, one would expect that the sum of particles and the dissolution is higher than the actual production. While the amount of aragonite produced in high latitudes equals $0.009 \mathrm{PgCy}^{-1}$, the quantity that dissolves or reaches the bottom equals $0.0273 \mathrm{PgC}^{-1}$, leaving an amount of $0.018 \mathrm{PgC}^{-1}$ to be lateral transport and/or transient behaviour. This is twice as much as the amount produced and thus significant for this area, while compared to the total aragonite production, it accounts for about $8.3 \%$. The changes in aragonite production 

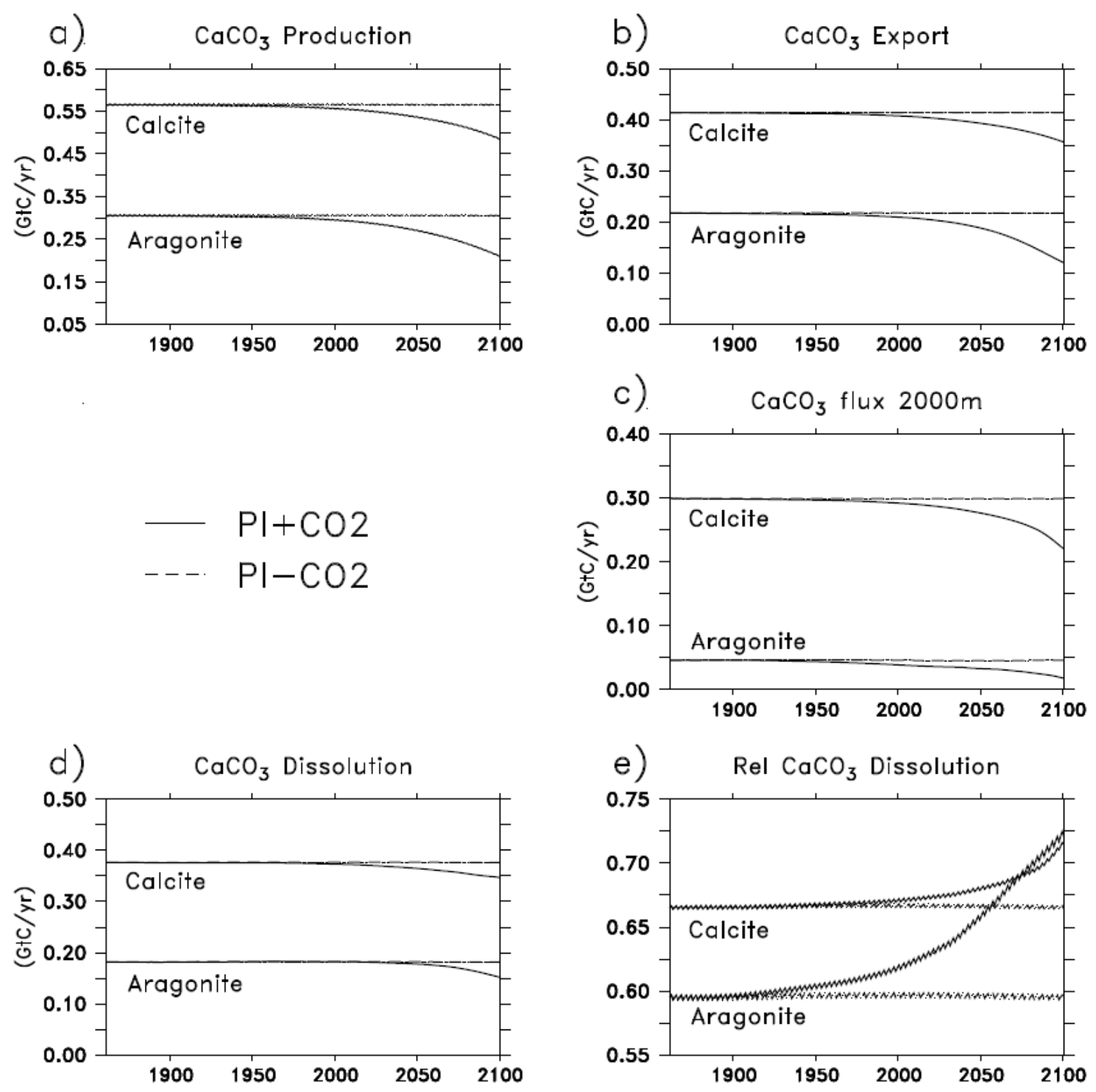

Fig. 5. Time series of global calcite and aragonite: (a) net production, (b) export, (c) sinking flux at $2000 \mathrm{~m}$, (d) dissolution and (e) total pelagic dissolution/net production. $\mathrm{PI}+\mathrm{CO}_{2}$ represents model simulations with increasing $\mathrm{CO}_{2}$ while $\mathrm{PI}-\mathrm{CO}_{2}$ is the control run.

and dissolution suggest the potential for detrimental impacts of acidification on pteropods in the high latitudes, where shells of pteropods dominate the flux of $\mathrm{CaCO}_{3}$ (Collier et al., 2000; Honjo et al., 2000; Urban-Rich; 2001; Accornero et al., 2003; Tsurumi et al., 2005, Manno et al. 2007).

In the equatorial area, the calcite and aragonite production is reduced by 9.5 and $18 \%$, whereas the relative dissolution has increased by $4 \%$ and $5 \%$, respectively. This change is small compared to the percentages presented for the high latitudes, however the quantitative impacts on calcite and aragonite producers may be large due to the moderate to high calcification rates observed in equatorial regions (e.g. Deuser and
Ross, 1989; Fabry and Deuser, 1991; Kalberer et al., 1993; Fischer et al., 1996). In year 2100 the model still predicts a large area with aragonite saturation values above 2 in the gyres (Fig. 4). However, near the coast and in the equatorial upwelling area the saturation state is already close to 1 in year 2100. In areas with upwelling of DIC enriched deepwater the saturation state may decrease rapidly with increasing $\mathrm{CO}_{2}$ concentrations. We would thus expect that shortly after year 2100 the surface waters in the equatorial and especially upwelling areas would become undersaturated, which would probably prevent large amounts of aragonite from being produced in this area. 
In comparison to the pelagic ocean (Table 1 ), $\mathrm{CaCO}_{3}$ production in benthic calcifying systems $(<100 \mathrm{~m})$ is low, of 0.02-0.1 $\mathrm{PgC}^{-1}$ (Milliman and Droxler, 1996). The accumulation in the shallow depth sediments is reported to be 0.01-0.1 $\mathrm{PgC}^{-1}$ (Milliman and Droxler, 1996). As the coastal areas are usually oversaturated, very little dissolution takes place in the water column and in the sediments. With a "business as usual" $\mathrm{CO}_{2}$ emissions scenario the saturation state of the surface waters with respect to calcite and aragonite is projected to decrease by $45 \%$ within year 2100 and by $73 \%$ by year 2300 (Caldeira and Wickett, 2005; Andersson et al., 2006). Andersson et al. (2006) suggested that this could lead to a reduction in carbonate production rate in coastal areas of $40 \%$ by 2100 and by $90 \%$ by year 2300 , using a linear relationship between saturation state and calcification. As the amount of dissolution is low in the coastal areas, the ratio dissolution/calcification in this area might thus increase significantly. The feedbacks on atmospheric $p \mathrm{CO}_{2}$ of changes in the budget of shallow water benthic carbonates can however not be extrapolated from our study.

\section{Conclusions}

The work presented here is intended as a first step towards understanding the role of aragonite production and dissolution in the global $\mathrm{CaCO}_{3}$ budget and its evolution with increasing atmospheric $p \mathrm{CO}_{2}$. Aragonite was included in the global biogeochemical model PISCES, where the parameterized production and dissolution were implemented with analogy to the corresponding terms for calcite. The production was assigned to mesozooplankton as a function of mesozooplankton biomass and aragonite saturation state of ambient waters. The marine carbonate cycle is well reproduced by the model with net global carbonate production rates corresponding to recent data-based estimates (Table 1). Except from a possible overestimation by the model of produced aragonite in the equatorial zones (Fabry, 1990), the model predicts a global spatial variability in aragonite production and dissolution consistent with literature.

With aragonite included in the model, the total $\mathrm{CaCO}_{3}$ water column dissolution above $2000 \mathrm{~m}$ constitutes $58 \%$ of the modeled dissolution corresponding to estimates. In contrast, the corresponding value for the calcite-only version is $38 \%$. The model provides less $\mathrm{CaCO}_{3}$ dissolution in the upper $1000 \mathrm{~m}$ than reported (Milliman and Droxler, 1996), indicating that other mechanisms in addition to aragonite dissolution are needed to explain the entire loss of $\mathrm{CaCO}_{3}$ in the upper part of the water column. Compared to the calciteonly model version however, taking into account production and dissolution of aragonite in addition to calcite in PISCES significantly improves the vertical distribution of dissolution rates and fluxes by allowing water column $\mathrm{CaCO}_{3}$ dissolution above the calcite saturation horizon. Our results support the hypothesis that high dissolution fluxes in the upper part of the water column may largely be attributed to aragonite.

Effects of increasing atmospheric $\mathrm{CO}_{2}$ on the $\mathrm{CaCO}_{3}$ production and dissolution were studied using the SRES A2 scenario. Following the increasing values of atmospheric $\mathrm{CO}_{2}$, a threshold phase seems to occur around year 2050; at this time already the entire ocean surface is predicted to have suboptimal conditions for aragonite production and some surface water areas in the Arctic are undersaturated with respect to aragonite. As a result of the decreasing saturation state, the global modeled aragonite production is reduced by almost one third in year 2100 compared to pre-industrial times. The global relative aragonite dissolution (dissolution/production) has increased by $12 \%$. At latitudes above $40^{\circ}$, where production rates of aragonite are estimated to be highest, a decrease in aragonite production of substantially $65 \%$ is projected. Here the relative aragonite dissolution increases by $72 \%$. Total global modeled $\mathrm{CaCO}_{3}$ production has decreased by $19 \%$ by the end of the SRES A2 scenario, compared to approximately $15 \%$ for the model version without aragonite. Most of the increase in relative dissolution takes place in the upper part of the water column. While the feedback to atmospheric $\mathrm{CO}_{2}$ of reduced $\mathrm{CaCO}_{3}$ production and increased relative dissolution is estimated to be small (Gehlen et al., 2007), the predicted changes in aragonite production and dissolution highlight potential impacts of changing carbonate chemistry on aragonite producing organisms and the surrounding ecosystem of the pelagic ocean, especially in subpolar and polar areas.

The inclusion of $1 / 3$ aragonite is in the upper range of most estimates, leading to a probable overestimation of the quantitative changes in aragonite production and dissolution with increasing atmospheric $p \mathrm{CO}_{2}$. Alternatively, if the decrease in production of pteropod aragonite follows a linear parameterization as found by Langdon (2005) for corals instead of the curve fitted to experiments with coccolithophores, a faster response to the increasing $\mathrm{CO}_{2}$ is expected. This would point towards an underestimation of the quantitative reduction in aragonite production suggested by our model. Thus further exploration is needed to quantify the contribution of aragonite to the total $\mathrm{CaCO}_{3}$ budget and the evolution of aragonite production and dissolution in the future ocean.

Acknowledgements. This work was supported through EU grants 511106-2 (FP6 RTD project EUR-OCEANS) and GOCE-511176 (FP6 RTP project CARBOOCEAN) by the European Commission. We would like to thank Christian Ethe for assistance with the PISCES model. M. G. acknowledges a visiting fellowship by the Hanse Institut for Advanced Study (Delmenhorst/Germany) and F. J. support by the Swiss National Science Foundation. Two anonymous reviewers helped to improve the manuscript. This is publication number 2978 from LSCE.

Edited by: J. Middelburg 


\section{References}

Accornero, A., Manno, C., Esposito, F., and Gambi, M. C.: The vertical flux of particulate matter in the polynya of Terra Nova Bay. Part II. Biological components, Antarctic Science 15(2), 175$188,2003$.

Allredge, A. and Silver, M.: Characteristics, dynamics and significance of marine snow, Prog. Oceanogr., 20, 41-82, 1988.

Andersson, A. J., MacKenzie, F. T., and Lerman, A.: Coastal ocean carbonate ecosystems in the high $\mathrm{CO}_{2}$ world of the Antropocene, Am J. Sci, 305, 875-918, 2005.

Antia, A. N., Suffrian, K., Holste, L., Müller, M. N., Nejstgaard, J. C., Simonelli, P., Carotenuto, Y., and Putzeys, S.: Dissolution of coccolithophorid calcite by microzooplankton and copepod grazing, Biogeosciences Discuss., 5, 1-23, 2008,

http://www.biogeosciences-discuss.net/5/1/2008/.

Arakaki, T. and Mucci, A.: A continuous and mechanistic description of calcite reaction-controlled kinetics in dilute solutions at 25 degrees $\mathrm{C}$ and $1 \mathrm{~atm}$ total pressure. Aquat. Geochem., 1, 105130, 1995.

Aumont, O., Orr, J. C., Jamous, D., Monfray, P., Marti, O., and Madec, G.: A degradation approach to accelerate simulations to steady-state in a 3-D tracer transport model of the global ocean, Climate Dynamics, 14(2), 101-116, 1998.

Aumont, O., Maier-Reimer, E., Blain, S. and Monfray, P.: An ecosystem model of the global ocean including $\mathrm{Fe}$, $\mathrm{Si}$, P colimitations, Glob. Biogeochem. Cy., 17(2), 1060, doi:10.1029/2001GB001745, 2003.

Aumont, O. and Bopp, L.: Globalizing results from ocean in situ iron fertilization studies, Glob. Biogeochem. Cy., 20, GB2017, doi:10.1029/2005GB002591, 2006.

Berelson, W. M., Balch, W. M., Najjar, R., Feely, R. A., Sabine, C., and Lee, K.: Relating estimates of $\mathrm{CaCO}_{3}$ production, export, and dissolution in the water column to measurements of $\mathrm{CaCO}_{3}$ rain into sediment traps and dissolution on the sea floor: A revised global carbonate budget, Glob. Biogeochem. Cy., 21, GB1024, doi:10.1029/2006GB002803, 2007.

Berger, W. H.: Deep-Sea carbonate: pteropod distribution and the aragonite compensation depth, Deep-Sea Res., 25, 447-452, 1978.

Berner, R. A.: Sedimentation and Dissolution of Pteropods in the Ocean, in The Fate of Fossil Fuel $\mathrm{CO}_{2}$ in the Oceans, N. R. Andersen and A. Malahoff, editors., 243-260, Plenum Press, New York, 1977.

Berner, R. A. and Honjo, S.: Pelagic sedimentation of aragonite: its geochemical significance, Science, 211, 940-942, 1981.

Berner, R. A. and Morse, J. W.: Dissolution kinetics of calcium carbonate in seawater: IV. Theory of calcite dissolution. Am. J. Sci. 274, 108-134, 1974.

Betzer, P. R., Byrne, R. H., Acker, J. G., Lewis, C. S., Jolley, R. R., and Feely, R. A.: The oceanic carbonate system: a reassessment of biogenic controls, Science 226, 1074-1077, 1984.

Bijma, J., Spero, H. J., and Lea, D. W.: Reassessing foraminiferal stable isotope geochemistry: Impact of the oceanic carbonate system (experimental results), in: Use of Proxies in Paleoceanography: Examples From the South Atlantic, edited by: Fischer, G. and Wefer, G., 489-512, Springer, New York, 1999.

Broecker, W. S. and Takahashi, T.: The relationship between lysocline depth and in situ carbonate ion concentration, Deep Sea Res. 25, 65-95, 1978.
Buitenhuis, E., Le Quéré, C., Aumont, O., Beaugrand, G., Bunker, A., Hirst, A., Ikeda, T., O’Brien, T., Piontkovski, S., and Straile, D.: Biogeochemical fluxes through mesozooplankton, Glob. Biogeochem. Cy., 20, GB2003, doi:10.1029/2005GB002511, 2006.

Busenberg, E. and Plummer, L. N.: A comparative study of the dissolution and crystal growth kinetics of calcite and aragonite. In: F.A. Mumptom, Editor, Studies Diagenesis U.S.G.S. Bull. Vol. 1578, US Department of the Interior, Reston, 139-168, 1986.

Byrne, R. H., Acker, J. G., Betzer, P. R., Feely, R. A. and Cates, M. H.: Water column dissolution of aragonite in the Pacific Ocean, Nature, 312, 321-326, 1984.

Caldeira, K. and Wickett, M. E.: Anthropogenic carbon and ocean pH, Nature, 425, 365, 2003.

Caldeira, K. and Wickett, M. E.: Ocean model predictions of chemistry changes from carbon dioxide emissions to the atmosphere and ocean, J. Geophys. Res., 110, C09S04, doi:10.1029/2004JC002671, 2005.

Chung, S.-N., Lee, K., Feely, R. A., Sabine, C. L., Millero, F. J., Wanninkhof, R., Bullister, J. L., Key, R. M., and Peng, T.-H.: Calcium carbonate budget in the Atlantic Ocean based on water column inorganic carbon chemistry, Glob. Biogeochem. Cy., 17, 1093, doi:10.1029/2002GB002001, 2003.

Collier, R., Dymond, J., Honjo, S., Manganini, S., Francois, R., and Dunbar, R.: The vertical flux of biogenic and lithogenic material in the Ross Sea: moored sediment trap observations 1996-1998, Deep-Sea Res. II, 47, 3491-3520, 2000.

Delille, B., Harlay, J., Zondervan, I., Jacquet, S., Chou, L., Wollast, R., Bellerby, R. G. J., Frankignoulle, M., Borges, A. V., Riebesell, U., and Gattuso, J.-P.: Response of primary production and calcification to changes of $p \mathrm{CO}_{2}$ during experimental blooms of the coccolithophorid Emiliania huxleyi, Glob. Biogeochem. Cy., 19, GB2023, doi:10.1029/2004GB002318, 2005.

Deuser, W. G. and Ross, E. H.: Seasonally abundant planktonic foraminifera of the Sargasso Sea - succession, deep-water fluxes, isotopic compositions, and paleoceanographic implications, J. Foramin. Res., 19, 268-293, 1989.

Dilling, L. and Allredge, A. L.: Fragmentation of marine snow by swimming macrozooplankton: A new process impacting carbon cycling in the sea, Deep Sea Res. Part I, 47, 1227-1245, 2000.

Dittert, N., Corrin, L., Bakker, D., Bendsen, J., Gehlen, M., Heinze, C., Maier-Reimer, E., Michalopoulus, P., Soetaert, K. E. R., and Tol, R. J. S.: Integrated data sets of the FP5 Research Project ORFOIS: Origin and fate of biogenic particle fluxes in the ocean and their interactions with atmospheric $\mathrm{CO} 2$ concentrations as well as the marine sediment, Vol. 1, WDC-MARE Reports 0002, 2005.

Fabry, V. J.: Aragonite production by pteropod mollusks in the subarctic Pacific, Deep-Sea Res., 36, 11, 1735-1751, 1989.

Fabry, V. J.: Shell growth rates of pteropod and heteropod mollusks and aragonite production in the open ocean: Implications for the marine carbonate system, J. Mar. Res., 48, 209-222, 1990.

Fabry, V. J. and Deuser, W. G.: Aragonite and magnesium calcite fluxes to the deep Sargasso Sea, Deep-Sea Res. Part A., Oceanographic Research Papers, 38, 713-728, 1991.

Feely, R. A. and Chen, C.-T. A.: The effect of excess $\mathrm{CO}_{2}$ on the calculated calcite and aragonite saturation horizons in the northeast Pacific, Geophys. Res. Lett., 9(11), 1294-1297, 1982.

Feely, R. A., Sabine, C. L., Lee, K., Millero, F. J., Lamb, M. F., 
Greeley, D., Bullister, J. L., Key, R. M., Peng, T.-H., Kozyr, A., Ono, T., and Wong, C. S.: In situ calcium carbonate dissolution in the Pacific Ocean, Glob. Biogeochem. Cy., 16, 1144, doi:10.1029/2002GB001866, 2002.

Feely, R. A., Sabine, C. L., Lee, K., Berelson, W., Kleypas, J., Fabry, V. J. and Millero, F. J.: Impact of anthropogenic $\mathrm{CO}_{2}$ on the $\mathrm{CaCO}_{3}$ system in the oceans, Science, 305, 362-366, 2004.

Fischer, G., Donner, B., Ratmeyer, V., Davenport, R., and Wefer, G.: Distinct year-to-year particle flux variations off Cape Blanc during 1988-1991: Relation to $\delta^{18} \mathrm{O}$-deduced sea-surface temperatures and trade winds, J. Mar. Res., 54, 73-98, 1996.

Fischer, G. and Karakas G.: Sinking rates of particles in biogenic silica- and carbonate-dominated production systems of the Atlantic Ocean: implications for the organic carbon fluxes to the deep ocean, Biogesciences Discuss., 5, 2541-2581, 2008.

Friis K., Najjar, R. G., Follows, M. J., and Dutkiewicz, S.: Possible overestimation of shallow-depth calcium carbonate dissolution in the ocean, Glob. Biogeochem. Cy., 20, GB4019, doi:10.1029/2006GB002727, 2006.

Frost, B. W.: Grazing control of phytoplankton stock in the open subarctic Pacific Ocean: A model assessing the role of mesozooplankton, particularly the large calanoid copepods Neocalanus spp., Mar. Ecol. Prog. Ser., 39, 49-68, 1987.

Gattuso J.-P., Frankignoulle, M., Bourge, I., Romaine, S., and Buddemeier, R. W.: Effect of calcium carbonate saturation of seawater on coral calcification, Global and Planetary Change, 18, 37-46, 1998.

Gehlen, M., Bassinot, F. C., Chou, L., and McCorkle, D.: Reassessing the dissolution of marine carbonates. Part I: Solubility, Deep Sea Res. I, 52, 1445-1460, doi:10.1016/j.dsr.2005.03.010, 2005.

Gehlen, M., Bassinot, F. C., Chou, L., and McCorkle, D.: Reassessing the dissolution of marine carbonates. Part II: Reaction kinetics. Deep-Sea Res. I, 52, 1461-1476, doi:10.1016/j.dsr.2005.03.011, 2005.

Gehlen M., Bopp, L., Emprin, N., Aumont, O., Heinze, C., and Ragueneau, O.: Reconciling surface ocean productivity, export fluxes and sediment composition in a global biogeochemical ocean model, Biogeosciences, 3, 521-537, 2006,

http://www.biogeosciences.net/3/521/2006/.

Gehlen M., Gangst $\varnothing$, R., Schneider, B., Bopp, L., Aumont, O., and Ethe, $\mathrm{C} .:$ The fate of pelagic $\mathrm{CaCO}_{3}$ production in a high $\mathrm{CO}_{2}$ ocean: A model study, Biogesciences 4, 505-519, 2007.

Goyet, C., Healy, R. J., and Ryan, J. P.: Global distribution of total inorganic carbon and total alkalinity below the deepest winter mixed layer depths, ORNL/CDIAC-127, NDP-076, Carbon Dioxide Information Analysis Center, Oak Ridge National Laboratory, US Department of Energy, Oak Ridge, Tennessee, 2000.

Hales, B.: Respiration, dissolution, and the lysocline, Paleoceanography, 18, 1099-1113, 2003.

Harris, R. P.: Zooplankton grazing on the coccolithophore Emiliania huxleyi and its role in inorganic carbon flux, Mar. Biol., 119, 431-439, 1994.

Hoegh-Guldberg, O., Mumby, P. J., Hooten, A. J. et al.: Coral reefs under rapid climate change and ocean acidification, Science, 318 , 1737-1742, 2007.

Honjo, S. and Erez, J.: Dissolution rates of calcium carbonate in the deep ocean: an in-situ experiment in the northern Atlantic Ocean, Earth and Planetary Science Letters, 40, 287-300, 1978.

Honjo, S. and Roman, M. R.: Marine copepod fecal pellets: pro- duction, preservation and sedimentation, J. mar. Res. 36, 45-57, 1978.

Honjo, S., Francois, R., Manganini, S., Dymond, J., and Collier, R.: Particle fluxes to the interior of the Southern Ocean in the Western Pacific sector along $170^{\circ} \mathrm{W}$, Deep-Sea Res. II, 47, 35213548, 2000.

Iglesias-Rodriguez, M. D., Armstrong, R., Feely, R., Hood, R., Kleypas, J., Milliman, J. D., Sabine, C., and Sarmiento, J.: Progress made in study of ocean's calcium carbonate budget, EOS, 83(34), 365, 374-375, 2002.

Jansen, H., Zeebe, R. E., and Wolf-Gladrow, D. A.: Modeling the dissolution of settling $\mathrm{CaCO}_{3}$ in the ocean, Glob. Biogeochem. Cy., 16(2), 1027, 10.1029/2000GB001279, 2002.

Kalberer, M., Fischer, G., Pätzold, J., Donner, B., Segl, M., and Wefer, G.: Seasonal sedimentation and stable isotope records of pteropods off Cape Blanc, Mar. Geol., 113, 305-320, 1993.

Keir, R.: The dissolution kinetics of biogenic calcium carbonates in seawater, Geochimica et Cosmochimica Acta, 44, 241-252, 1980

Key, R. M., Kozyr, A., Sabine, C. L., Lee, K., Wanninkhof, R., Bullister, J. L., Feely, R. A., Millero, F. J., Mordy, C., and Peng, T.-H.: A global ocean carbon climatology: Results from Global Data Analysis Project (GLODAP), Glob. Biogeochem. Cy., 18, GB4031, doi:10.1029/2004GB002247, 2004.

Kleypas, J. A., Buddemeier, R. W., Archer, D., Gattuso, J.-P., Langdon, C., and Opdyke, B. N.: Geochemical consequences of increased atmospheric carbon dioxide on coral reefs, Science, 284 , 118-120, 1999.

Kleypas, J. A., Feely, R. A., Fabry, V. J., Langdon, C., Sabine, C. L., and Robbins, L. L.: Impacts of ocean acidification on coral reefs and other marine calcifiers: A guide for future research, report of a workshop held 18-20 April 2005, St. Petersburg, FL, sponsored by NSF, NOAA, and the US Geological Survey, 88 pp., 2006.

Lalli, C. M. and Gilmer, R. W.: Pelagic snails: The Biology of Holoplanktonic Gastropod Mollusks, Stanford University Press, 1989.

Langdon, C., Broecker, W. S., Hammond, D. E., Glenn, E., Fitzsimmons, K., Nelson, S. G., Peng, T.-H., Hajdas, I., and Bonani, G.: Effect of elevated $\mathrm{CO}_{2}$ on the community metabolism of an experimental coral reef, Glob. Biogeochem. Cy., 17(1), 1011, doi:10.1029/2002GB001941, 2003.

Langdon, C. and Atkinson, M. J.: Effect of elevated $p \mathrm{CO}_{2}$ on photosynthesis and calcification of corals and interactions with seasonal change in temperate/irradiance and nutrient enrichment, $\mathrm{J}$. Geophys. Res., 110, C09S07, doi:10.1029/2004JC002576, 2005.

Manno, C., Sandrini, S., Tositti, L., and Accornero, A.: First stages of degradation of Limacina helicina shells observed above the aragonite chemical lysocline in Terra Nova Bay (Antarctica), J. Mar. Sys., 68, 91-102, 2007.

Madec, G. P., Delecluse, P., Imbard, M., and Lévy, C.: OPA 8.1 Ocean general circulation model reference manual, Notes du pole de modélisation, IPSL, 1998.

Milliman, J. D.: Production and accumulation of calcium carbonate in the ocean: budget of a nonsteady state, Glob. Biogeochem. Cy., 7, 927-957, 1993.

Milliman, J. D. and Droxler, A. W.: Neritic and pelagic carbonate sedimentation in the marine environment: ignorance is not bliss, Geol. Rundsch., 85, 496-504, 1996. 
Milliman, J. D., Troy, P. J., Balch, W. M., Adams, A. K., Li, Y.H., and Mackenzie, F. T.: Biologically mediated dissolution of calcium carbonate above the chemical lysocline?, Deep-Sea Research I, 46, 1653-1669, 1999.

Moloney, C. L. and Field, J. G.: The size-based dynamics of plankton food webs. I. A simulation model of carbon and nitrogen flows, J. Plankton Res., 1003-1038, 1991.

Morse, J. W. and Berner, R. C.: Dissolution kinetics of calcium carbonate in seawater. II: a kinetic origin for the lysocline, Am. J. Sci., 272, 840-851, 1972.

Morse, J. W.: Dissolution kinetics of calcium carbonate in seawater. VI. The near-equilibrium dissolution kinetics of carbonate-rich deep-sea sediments, Am. J. Sci., 278, 344-353, 1978.

Morse, J. W., de Kanel, J., and Harris, K.: Dissolution kinetics of calcium carbonate in seawater. VII. The dissolution kinetics of synthetic aragonite and pteropod tests, Am. J. Sci, 279, 482-502, 1979.

Morse, J. and MacKenzie, F. T.: Geochemistry of Sedimentary Carbonates, 707 pp., Elsevier, New York, 1990.

Morse, J. W. and Arvidson, R. S.: The dissolution kinetics of major sedimentary carbonate minerals, Earth-Sci. Rev., 58, 51-84, 2002.

Morse, J. W., Arvidson, R. S., and Lüttge, A.: Calcium carbonate formation and dissolution, Chem. Rev. 107, 342-381, 2007.

Mucci, A.: The solubility of calcite and aragonite in seawater at various salinities, temperatures and one atmosphere total pressure, Amer. J. Sci., 283, 780-799, 1983.

Orr, J. C., Fabry, V. J., Aumont, O., et al.: Anthropogenic ocean acidification over the twenty-first century and its impact on calcifying organisms, Nature, 437, 681-686, 2005.

Plummer, L. N., Wigley, T. M. L., and Parkhurst, D. L.: The kinetics of calcite dissolution in $\mathrm{CO}_{2}$-water systems at $5-60^{\circ} \mathrm{C}$ and 0.0 to 1.0 atm $\mathrm{CO}_{2}$, Am. J. Sci., 278, 179-216, 1978.

Pond, D. W., Harris, R. P., and Brownlee, C.: A microinjection technique using a $\mathrm{pH}$-sensitive dye to determine the gut $\mathrm{pH}$ of Calanus-Helgolandicus, Mar. Biol., 123, 75-79, 1995.

Riebesell U., Zondervan, I., Rost, B., Tortell, P. D., Zeebe, R. E., and Morel, F. M. M.: Reduced calcification of marine plankton in response to increased atmospheric $\mathrm{CO}_{2}$, Nature, 407, 364367, 2000.

Royal Society: Ocean acidification due to increasing atmospheric carbon dioxide, Document 12/05, Royal Society: London, 2005.

Sabine, C. L., Key, R. M., Feely, R. A., and Greeley, D.: Inorganic carbon in the Indian Ocean: Distribution and dissolution processes, Glob. Biogeochem. Cy., 16, 1067, doi:10.1029/2002GB001869, 2002.

Sarmiento, J. L., Dunne, J., Gnanadesikan, A., Key, R. M., Matsumoto, K., and Slater, R.: A new estimate of the $\mathrm{CaCO}_{3}$ to organic carbon export ratio, Glob. Biogeochem. Cy., 16, 1107, doi:10.1029/2002GB001919, 2002.
Sawada, K., Handa, N., and Nakatsuka, T.: Production and transport of long-chain alkenones and alkyl alkenoates in a sea water column in the northwestern Pacific off central Japan, Mar. Chem., 59, 219-234, 1988.

Sciandra, A., Harlay, J., Lefèvre, D., Lemée, R., Rimmelin, P., Denis, M., and Gattuso, J.-P.: Response of coccolithophorid Emiliania huxleyi to elevated partial pressure of $\mathrm{CO}_{2}$ under nitrogen limitation, Marine Ecology Progress Series, 261, 111-222, 2003.

Steinacher, M: Ocean acidification and changes in marine productivity in simulations with the fully coupled 3-D climate model CSM1.4-carbon, Diploma thesis, University of Bern, Bern, 2007.

Stemmann, L., Jackson, G. A., and Gorsky, G.: A vertical model of particle size distributions and fluxes in the mid-water column that includes biological and physical processes, Part II, Application to a three year survey in the NW Mediterranean Sea, Deep Sea Res. Part I, 51, 885-908.

Sverdrup, H. U., Johnson, M. W., and Fleming, R. H.: The oceans, their physics, chemistry and general biology, New York: Prentice-Hall, 1942.

Tsurumi, M., Mackas, D. L., Whitney, F. A., Dibacco, C., Galbraith, M. D., and Wong, C. S.: Pteropods, eddies, carbon flux, and climate variability in the Alaska Gyre, Deep-Sea Research II, 52, 1037-1053, 2005.

Urban-Rich, J., Dagg, M., and Peterson, J.: Copepod grazing on phytoplankton in the Pacific sector of the Antarctic Polar Front, Deep-Sea Res. II, 48, 4223-4246, 2001.

Walter, L. M. and Morse, J. W.: The dissolution kinetics of shallow marine carbonates in seawater: a laboratory study, Geochim. Cosmochim. Acta, 49, 1503-1514, 1985.

Wolf-Gladrow, D. A., Riebesell, U., Burkhardt, S., and Bijma, J.: Direct effects of $\mathrm{CO}_{2}$ concentration on growth and isotopic composition of marine plankton, Tellus, 51B(2), 461-476, 1999.

Wollast, R. and Chou, L.: Distribution and fluxes of calcium carbonate along the continental margin in the Gulf of Biscay, Aquatic Geochemistry, 4(3-4), 369-393, 1998.

Zeebe, R. E. and Wolf-Gladrow, D.: $\mathrm{CO}_{2}$ in seawater: Equilibrium, kinetics, isotopes, Elsivier Oceanography Series, 65, 346 pp., 2001.

Zondervan, I., Rost, B., and Riebesell, U.: Effect of $\mathrm{CO}_{2}$ concentration on the PIC/POC ratio in the coccolithophore Emiliania huxleyi grown under light-limiting conditions and different daylengths, J. Exp. Mar. Biol. Ecol., 272, 55-70, 2002.

Zondervan, I., Zeebe, R. E., Rost, B., and Riebesell, U.: Decreasing marine biogenic calcification: A negative feedback on rising atmospheric $p \mathrm{CO}_{2}$, Glob. Biogeochem. Cy., 15(2) 507-516, 2001. 